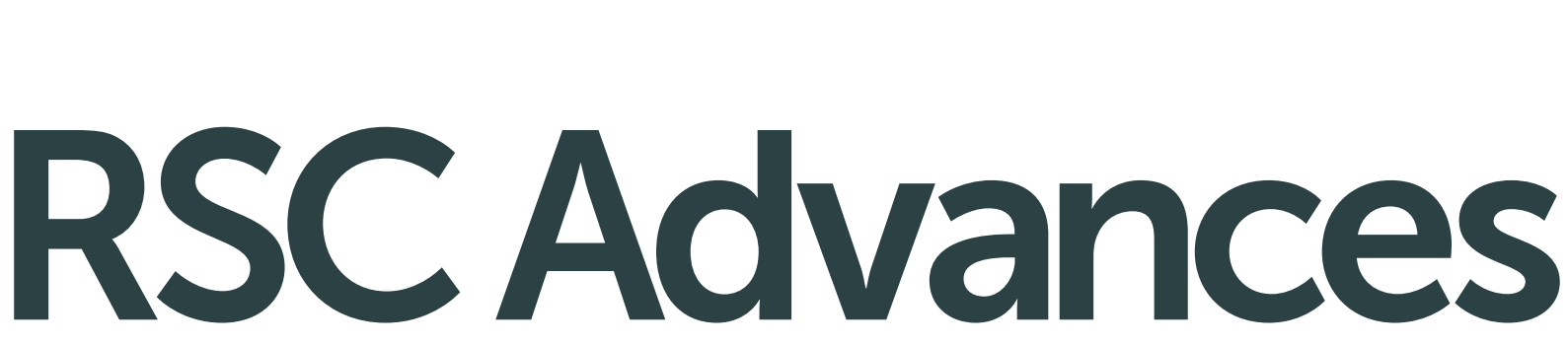

This article can be cited before page numbers have been issued, to do this please use: T. N, M. S. S Z, P. S R and R. Kapanaiah, RSC Adv., 2015, DOI: 10.1039/C5RA20430E.

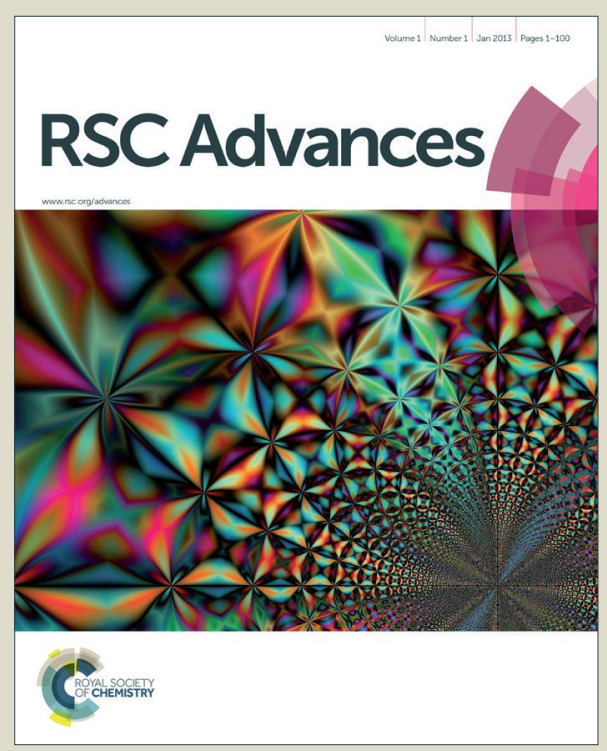

This is an Accepted Manuscript, which has been through the Royal Society of Chemistry peer review process and has been accepted for publication.

Accepted Manuscripts are published online shortly after acceptance, before technical editing, formatting and proof reading. Using this free service, authors can make their results available to the community, in citable form, before we publish the edited article. This Accepted Manuscript will be replaced by the edited, formatted and paginated article as soon as this is available.

You can find more information about Accepted Manuscripts in the Information for Authors.

Please note that technical editing may introduce minor changes to the text and/or graphics, which may alter content. The journal's standard Terms \& Conditions and the Ethical guidelines still apply. In no event shall the Royal Society of Chemistry be held responsible for any errors or omissions in this Accepted Manuscript or any consequences arising from the use of any information it contains. 


\title{
Efficient Microwave synthesis of novel Aromatic Esters catalyzed by Zirconia and its modified forms: Kinetic study
}

\author{
N. Thimmaraju ${ }^{1,2}$, S. Z. Mohamed Shamshuddin ${ }^{* 1,2}$, S. R. Pratap ${ }^{1,2}$ and Raja Kapanaiah ${ }^{3}$ \\ ${ }^{1}$ Chemistry Research Laboratory, HMS Institute of Technology, Tumkur-572104, Karnataka, \\ India. \\ ${ }^{2}$ Research and Development Center, Bharathiar University, Coimbatore, India. \\ ${ }^{3}$ Chemisty Department, Bangalore university, Bangalore, India. \\ *Corresponding author: E-mail address: mohamed.shamshuddin@gmail.com
}

Phone no: $+91-9844718742$

\begin{abstract}
A series of solid acids such as $\mathrm{ZrO}_{2}, 5 \% \mathrm{Mo}(\mathrm{VI}) / \mathrm{ZrO}_{2}, 10 \% \mathrm{Mo}(\mathrm{VI}) / \mathrm{ZrO}_{2}, 20 \% \mathrm{Mo}(\mathrm{VI}) / \mathrm{ZrO}_{2}$ and $\mathrm{SO}_{4}{ }^{2-} / \mathrm{ZrO}_{2}$ were prepared. These solid acids were characterized by BET, $\mathrm{NH}_{3}-\mathrm{TPD} / \mathrm{n}$ butylamine back titration, powder-XRD, FT-IR spectroscopy, scanning electron microscopy (SEM), transmission electron microscopy (TEM) and ICP-OES techniques. The catalytic performance of these solid acids was evaluated in the synthesis of novel aromatic esters by the assistance of microwave irradiation and the catalytic activity of these solid acids was compared with pTsOH. The results clearly indicated that the zirconia based solid acids are efficient green catalysts for esterification reactions, which gave maximum yield of ester in shorter reaction time and comparable to the catalytic activity of pTsOH Brönsted acid. Kinetic studies were carried out to calculate the temperature coefficients (1.66 and 1.56) and energy of activation (66.82 $\mathrm{KJmol}^{-1}$ and $58.93 \mathrm{KJmol}^{-1}$ ) for $\mathrm{SO}_{4}{ }^{2-} / \mathrm{ZrO}_{2}$ and $\mathrm{pTsOH}$ respectively. Pre-adsorption studies revealed that the reaction follows the Langmuir-Hinshelwood mechanism. $\mathrm{SO}_{4}{ }^{2-} / \mathrm{ZrO}_{2}$ solid acid catalyst was found to be reactivable and reusable.
\end{abstract}


Keywords: Esterification; Kinetic studies; Temperature coefficient; Energy of activation; Langmuir-Hinshelwood; Zirconia; Modified zirconia.

\section{Introduction}

Many organic transformations are assisted by heterogeneous solid acid catalysts such as metal oxides, mixed metal oxides, doped metal oxides, zeolites, resins, clays, etc., ${ }^{1-4}$. These solid acids can replace liquid acid catalysts like $\mathrm{H}_{2} \mathrm{SO}_{4}, \mathrm{HCl}, \mathrm{AlCl}_{3}, \mathrm{BF}_{3}, \mathrm{H}_{3} \mathrm{PO}_{4}, \mathrm{SnCl}_{4}, \mathrm{ZnCl}_{2}$, etc., ${ }^{5-6}$. The main advantages of solid acid catalysts are that they are eco-friendly and green because, solid acids are non-toxic, non corrosive, easy to recover and reusable for several times and also reduce or even eliminate the production of hazardous materials ${ }^{7-8}$.

Metal oxide based solid acids like zirconia $\left(\mathrm{ZrO}_{2}\right)$ as well as modified forms of zirconia is widely employed as catalysts in a number of acid catalyzed reactions. Such as, transesterification, esterification, alkylation, acetylation, hydrocarbon isomerization, synthesis of heterocyclic compounds, etc., ${ }^{7-14}$. It has been reported that $\mathrm{Mo}(\mathrm{VI})$ and $\mathrm{SO}_{4}{ }^{2-}$ ions impregnated on $\mathrm{ZrO}_{2}$ can increase the number of catalytically active sites of zirconia and also increases the more active tetragonal phase of zirconia which is even catalytically active at higher temperatures.

Microwave (MW) irradiation assisted organic reactions have been widely used in small scale as well as large scale organic synthesis, because polar organic molecules selectively absorb MW energy ${ }^{15-18}$. MW irradiated organic synthesis gives higher yield of the products in shorter reaction times when compared to conventional thermal reactions. Due to shorter reaction times the catalyst could be preserved from decomposition and also increased catalytic efficiency could be expected ${ }^{19}$. Moreover, microwave heating accelerate the chemical reactions under increased pressure conditions because solvents can rapidly get superheated to temperatures $>100{ }^{\circ} \mathrm{C}$ above its boiling point when irradiated under microwave conditions in a sealed vessel ${ }^{20-21}$. 
Esters are a group of organic compounds which are widely used in the synthesis of food additives, drugs, cosmetics, preservative solvents, perfumes, pharmaceuticals, plasticizers, lubricants, solvents, detergents, soaps, reaction intermediates, etc., ${ }^{22-29}$. Different approaches have been employed in both laboratory and commercial scale to prepare esters. The process of esterification may be enormously accelerated by the addition of corrosive reagents like sulfuric acid, hydrochloric acid ( $\mathrm{HCl})$, thionyl chloride, trimethyl silane (TMS) diazomethane, etc., ${ }^{26-31}$.

The main goal of this research work was to obtain suitable solid acid catalysts for esterification of aromatic carboxylic acids with aliphatic alcohols. Catalytic materials such as zirconia, $5 \% \mathrm{Mo}(\mathrm{VI}) / \mathrm{ZrO}_{2}, 10 \% \mathrm{Mo}(\mathrm{VI}) / \mathrm{ZrO}_{2}, 20 \% \mathrm{Mo}(\mathrm{VI}) / \mathrm{ZrO}_{2}$ and $\mathrm{SO}_{4}{ }^{2-} / \mathrm{ZrO}_{2}$ were prepared and characterized for their surface area, surface acidity, crystalinity, functional group, morphology, particle size and elemental analysis. The catalytic performance of the prepared catalytic materials was evaluated in the synthesis of some novel esters by the esterification of halogenated carboxylic acids with propanol under MW irradiation condition. The obtained reaction products were characterized by LCMS, ${ }^{1} \mathrm{H}$ NMR and ${ }^{13} \mathrm{C}$ NMR. Optimization of reaction conditions were carried out by varying the reaction time, temperature, molar ratio of reactants and amount of the catalyst. Kinetic study was taken up on a particular esterification reaction to find temperature coefficient and energy of activation of $\mathrm{SO}_{4}{ }^{2-} / \mathrm{ZrO}_{2}$ and $\mathrm{pTsOH}$. Reaction mechanism was also proposed by pre-adsorption study.

\section{Experimental}

\subsubsection{Chemicals}

Chemicals such as zirconyl nitrate octahydrate, ammonium molybdate, pTsOH and $\mathrm{H}_{2} \mathrm{SO}_{4}$ were supplied by M/S LOBA Chemie Ltd., India. Aromatic halogenated carboxylic acids and propanol were supplied by either Alfa-Aesar or Sigma Aldrich or Leonid. 


\subsubsection{Preparation of solid acids}

\section{i. $\quad$ Preparation of hydrated $\mathrm{ZrO}_{2}$}

Precipitation method was used to prepare hydrated zirconia $\left(\mathrm{Zr}(\mathrm{OH})_{4} .100 \mathrm{~g}\right.$ of zirconyl nitrate was dissolved in $250 \mathrm{~mL}$ of distilled water and the resulting solution was heated at $80{ }^{\circ} \mathrm{C}$ for $10 \mathrm{~min}$. To this solution, aqueous ammonia (1:1) was added drop wise with constant stirring. The obtained precipitate was filtered, washed with distilled water and dried in hot air oven at 120 ${ }^{\circ} \mathrm{C}$ for $12 \mathrm{~h}$.

\section{ii. Preparation of $\mathrm{Mo}(\mathrm{VI}) / \mathrm{ZrO}_{2}$}

$5 \% \mathrm{Mo}(\mathrm{VI}) / \mathrm{ZrO}_{2}(5 \mathrm{MZ}), 10 \% \mathrm{Mo}(\mathrm{VI}) / \mathrm{ZrO}_{2}(10 \mathrm{MZ})$ and $20 \% \mathrm{Mo}(\mathrm{VI}) / \mathrm{ZrO}_{2}(20 \mathrm{MZ})$ were prepared by impregnation method. Typically, $10 \mathrm{MZ}$ was prepared as follows: Zirconyl nitrate $(9.125 \mathrm{~g})$ and ammonium molybdate $(0.736 \mathrm{~g})$ were made into a paste with $10 \mathrm{~mL}$ of distilled water. The resulting paste was dried at $120^{\circ} \mathrm{C}$ for $12 \mathrm{~h}$ in hot air oven and the obtained solid was finely powdered.

\section{iii. Preparation of sulfated zirconia (SZ)}

Sulfated zirconia $\left(\mathrm{SO}_{4}{ }^{2-} / \mathrm{ZrO}_{2}\right)$ was prepared as follows: Previously prepared $\mathrm{Zr}(\mathrm{OH})_{4}$ was made into a paste with $6 \mathrm{~mL}$ of $3 \mathrm{M} \mathrm{H}_{2} \mathrm{SO}_{4}$. The resulting paste was dried at $120{ }^{\circ} \mathrm{C}$ for 12 $\mathrm{h}$ in a hot air oven and the obtained solid was finely powdered.

All the finely powdered solid acid catalytic materials were calcinated at $550{ }^{\circ} \mathrm{C}$ in a muffle furnace for $5 \mathrm{~h}$. 


\subsection{Characterization of solid acids}

Specific surface area of solid acid catalytic materials was determined by BET method. NOVA 1000 Quanta chrome high-speed gas sorption analyzer instrument was used to measure the specific surface area of all the prepared catalysts. The surface acidity of the solid acids were determined by $\mathrm{NH}_{3}$-TPD method using Plus Chemisorb 2705 (Micromeritics) as well as by nbutyl amine back titration technique using dry benzene solvent. PXRD patterns of these solid acids was obtained from X'pert Pro Philips diffractometer equipped with a Ni filtered $\mathrm{Cu}-\mathrm{K} \alpha$ radiation with $\lambda=1.5418 \AA$ using a graphite crystal monochromator with a scanning range $25^{\circ}$ $65^{\circ}$. The FT-IR spectras were recorded on with $4 \mathrm{~cm}^{-1}$ resolution using a Nicolet IR200 FT-IR Spectrophotometer in the range $400-4000 \mathrm{~cm}^{-1}$ using $\mathrm{KBr}$ as standard reference. SEM images of all the prepared catalysts were obtained using a JEOL JXA-8530F microscope and TEM images of SZ was performed on Philips CM200 electron microscope at an acceleration voltage of 20-200 $\mathrm{kV}$. The amount of molybdenum present in all $\mathrm{Mo}(\mathrm{VI}) / \mathrm{ZrO}_{2}$ samples were determined by ICPOES (Inductively Coupled Plasma-Optical Emission Spectrometer) analysis using Thermo-iCAP 6000 Series analyser.

\subsection{Catalytic activity studies of solid acids}

The esterification of various halogenated carboxylic acids with $n$-propanol or iso-propanol in the presence of solid acids was carried out in a pressurized reaction tube $(10 \mathrm{~mL})$ equipped with a magnetic stirrer, which was then irradiated at a particular temperature $\left(85-145^{\circ} \mathrm{C}\right)$ for a definet period of time (10-70 min) in a self tuning single mode Labmate ${ }^{\circledR}$ microwave synthesizer. After the completion of the reaction, the reaction mixture was cooled rapidly to room temperature by passing compressed nitrogen through the microwave cavity for 5 min. The catalyst was recovered by filtration and the organic layer was dried and diluted with $15 \mathrm{~mL}$ of ethyl acetate. 
The unreacted carboxylic acid was removed by washing with $5 \mathrm{~mL}$ of saturated sodium bicarbonate solution. The organic layer was dried over anhydrous sodium sulphate and evaporated in vacuum to get the desired product. Obtained product was characterized by ${ }^{1} \mathrm{H}$ NMR, ${ }^{13} \mathrm{C}$ NMR (Varian) and LCMS (Agilent).

The reaction parameters such as reaction time, reaction temperature, molar ratio of the reactants and amount of the solid acid catalyst were varied for optimization and to get more yield of esters. Kinetic study and pre-adsorption studies were also carried out for a particular esterification reaction.

\subsection{Reusability of solid acids}

In order to study the reusability of the solid acid catalysts, the used solid acid was filtered from the reaction mixture, washed with ethyl acetate, dried at $120^{\circ} \mathrm{C}$ for $1 \mathrm{~h}$ and calcined at 550 ${ }^{\circ} \mathrm{C}$ for $1 \mathrm{~h}$. Then, the re-activated solid acid was used for esterification reaction under optimized reaction conditions with fresh reaction mixture for five consecutive reaction cycles.

\section{Results and discussion}

\subsection{Characterization of solid acids}

The BET surface area (SA), total surface acidity (TSA) as well as acid site distribution obtained by NH3-TPD method of $\mathrm{ZrO}_{2}, 5 \mathrm{MZ}, 10 \mathrm{MZ}, 20 \mathrm{MZ}$ and SZ are listed in Table 1.

The surface area of solid acids was found to follow the order:

$$
\mathrm{ZrO}_{2}<5 \mathrm{MZ}<20 \mathrm{MZ}<10 \mathrm{MZ}<\mathrm{SZ}
$$

The surface area of zirconia was found to be least when compared to other solid acids. The surface area of zirconia enhances when incorporated with either $\mathrm{Mo}(\mathrm{VI})$ or $\mathrm{SO}_{4}{ }^{2-}$ ions. Compared 
to all the prepared solid acids, SZ showed highest surface area which may be due to cracking of $\mathrm{ZrO}_{2}$ into fine particles when treated with $\mathrm{SO}_{4}{ }^{2-}$ ions ${ }^{1}$. Among $\mathrm{MZ}$ catalytic materials, $10 \mathrm{MZ}$ was having higher specific surface area than either $5 \mathrm{MZ}$ or $20 \mathrm{MZ}$. It was observed that the surface area increases with an increase in the concentration of $\mathrm{Mo}(\mathrm{VI})$ ions which may be due to an increase in the stabilizing effect of $\mathrm{Mo}(\mathrm{VI})$ ions on $\mathrm{ZrO}_{2}$. When the concentration of $\mathrm{Mo}(\mathrm{VI})$ ions was increased beyond $10 \%$ the surface area was found to decrease which may be due to the blockage of zirconia pore structure by excess Mo(VI) ions. A similar observation has been reported by A. H. Zapien et al ${ }^{32}$.

Table 1. Physico-chemical properties of solid acid catalytic materials used in the present work.

\begin{tabular}{|c|c|c|c|c|c|c|c|}
\hline \multirow[b]{2}{*}{ Catalyst } & \multirow{2}{*}{$\begin{array}{c}\text { BET } \\
\text { surface } \\
\text { area }\left(\mathrm{m}^{2} / \mathrm{g}\right)\end{array}$} & \multicolumn{5}{|c|}{ Acid site distribution ( $\mathrm{mmol} / \mathrm{g})$} & \multirow[b]{2}{*}{$\begin{array}{c}\text { \% of } \\
\text { Mo(VI) }\end{array}$} \\
\hline & & Weak & Medium & Strong & $\begin{array}{c}\text { Very } \\
\text { strong }\end{array}$ & TSA & \\
\hline $\mathrm{ZrO}_{2}$ & 42.9 & 0.03 & 0.40 & - & - & $0.43(0.45)$ & - \\
\hline $5 \mathrm{MZ}$ & 79.7 & - & 0.20 & 0.70 & - & $0.90(0.89)$ & 4.96 \\
\hline $10 \mathrm{MZ}$ & 88.1 & - & 0.16 & 0.86 & - & $1.02(1.03)$ & 9.87 \\
\hline $20 \mathrm{MZ}$ & 83.6 & - & 0.18 & 0.77 & - & $0.95(0.93)$ & 20.04 \\
\hline SZ & 161.8 & - & - & 0.87 & 0.44 & $1.31(1.35)$ & - \\
\hline
\end{tabular}

Note: The TSA values obtained by n-butyl amine back titration technique are shown in the parenthesis. 
The TSA values of $\mathrm{ZrO}_{2}, 5 \mathrm{MZ}, 10 \mathrm{MZ}, 20 \mathrm{MZ}$ and $\mathrm{SZ}$ determined by $\mathrm{NH}_{3}$-TPD/n-butyl amine back titration technique are presented in Table 1. The TSA of the solid acids was found to follow the order: $\quad \mathrm{ZrO}_{2}<5 \mathrm{MZ}<20 \mathrm{MZ}<10 \mathrm{MZ}<\mathrm{SZ}$

The TSA values indicate that the impregnation of either $\mathrm{Mo}(\mathrm{VI})$ or $\mathrm{SO}_{4}{ }^{2-}$ ions has a strong impact on the acidic properties of zirconia.

When acid sites distribution of pure zirconia, MZ and SZ were compared, it was observed that pure zirconia consists of 'weak' and 'moderate' acid sites, MZ consists 'moderate' and 'strong' acid sites whereas SZ consists of 'strong' and 'very strong' acid sites. This type of acid sites distribution is in good agreement with the acid site distribution reported in the literature ${ }^{33-35}$.

The PXRD patterns of solid acids are shown in Fig. 1. As could be seen from the figure, both tetragonal and monoclinic phases are observed for pure zirconia. In case of $5 \mathrm{MZ}, 10 \mathrm{MZ}$, $20 \mathrm{MZ}$ and SZ, the intensity of the peaks corresponding to monoclinic phase was found to decrease. This shows that $\mathrm{Mo}(\mathrm{VI})$ or $\mathrm{SO}_{4}{ }^{2-}$ ions strongly influences phase modification of zirconia (monoclinic to the metastable tetragonal). For $10 \mathrm{MZ}$, it is interesting to note that PXRD peaks corresponding to monoclinic phase is very low and major peaks corresponding to tetragonal phase are observed. In case of $5 \mathrm{MZ}$ and $20 \mathrm{MZ}$, low intense peaks corresponding to monoclinic phase were also observed. In case of SZ, only tetragonal phase of zirconia could be observed. The incorporation of $\mathrm{SO}_{4}^{2-}$ ions may delay the formation of crystalinity of $\mathrm{ZrO}_{2}$ crystallites thus stabilizes it into metastable tetragonal phase. 


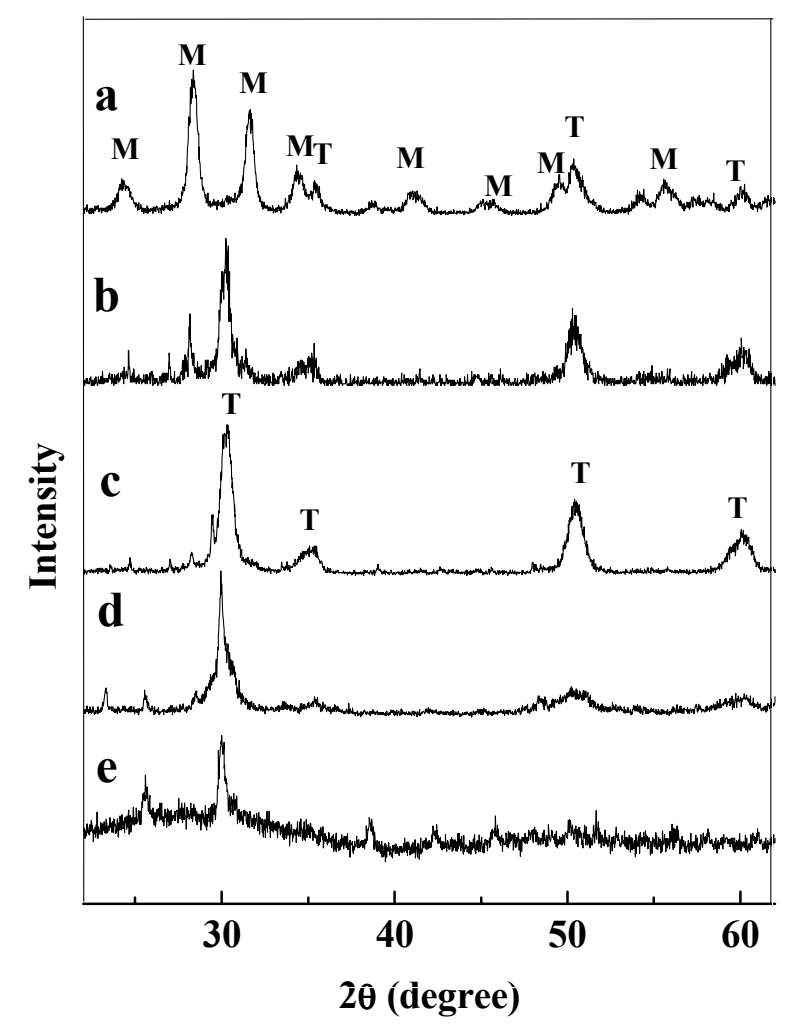

Figure 1. Powder XRD patterns of (a) $\mathrm{ZrO}_{2}$, (b) $5 \mathrm{MZ}$, (c) $10 \mathrm{MZ}$, (d) $20 \mathrm{MZ}$ and (e) SZ. [where, $M$ indicates monoclinic and $T$ indicates tetragonal phase].

Interestingly, a triangular correlation ship was found to exist between the surface area, TSA and crystalinity of the solid acid catalysts. This observation indicates that the tetragonal crystalline phase of zirconia could be responsible for higher surface area as well as higher surface acidity of zirconia catalysts ${ }^{36-37}$. 


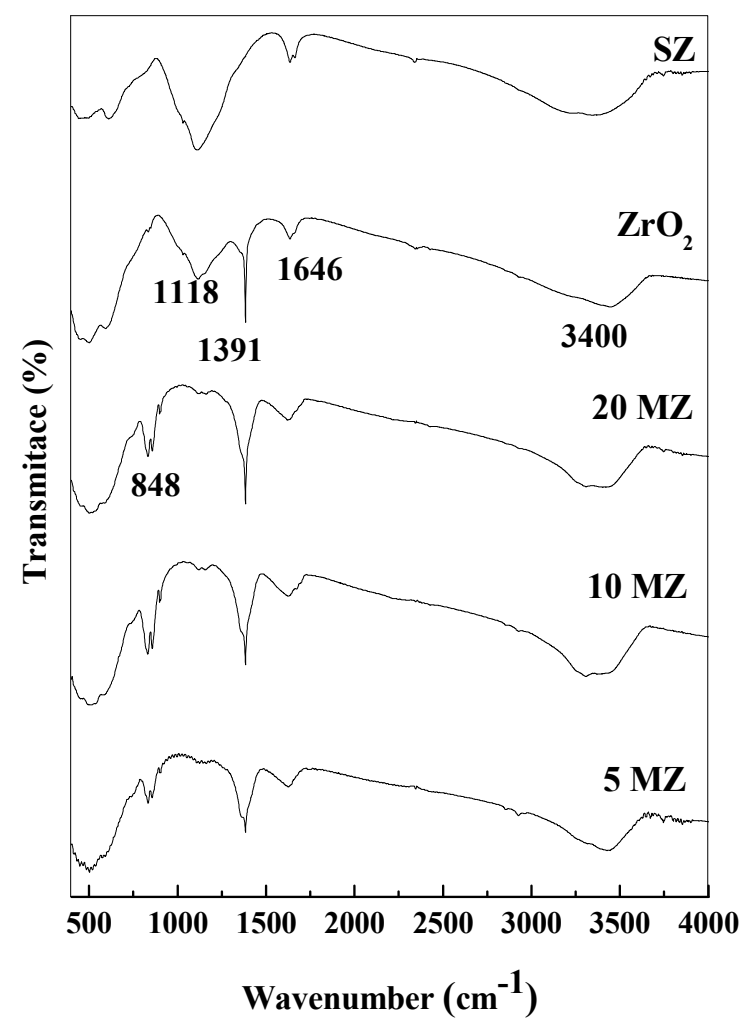

Figure 2. The FT-IR spectrum of $\mathrm{ZrO}_{2}, 5 \mathrm{MZ}, 10 \mathrm{MZ}, 20 \mathrm{MZ}$ and $\mathrm{SZ}$

The FT-IR spectra of all the prepared solid acids are given in Fig. 2. The bands at 1391 $\mathrm{cm}^{-1}$ and $1118 \mathrm{~cm}^{-1}$ can be due to $\mathrm{Zr}-\mathrm{OH}$ bending and $\mathrm{Zr}-\mathrm{O}-\mathrm{Zr}$ stretching modes respectively, which confirms the formation of $\mathrm{ZrO}_{2}$ phases. The broad band at $\sim 1646 \mathrm{~cm}^{-1}$ is attributed to the vibrations of acidic $-\mathrm{OH}$ and the band at $\sim 3400 \mathrm{~cm}^{-1}$ stretching mode with hydrogen bonding are present in all the catalysts ${ }^{38}$. In case of MZ samples the peak at $\sim 848 \mathrm{~cm}^{-1}$ is due to Mo-O-Mo stretching mode of vibration for $\mathrm{MoO}_{3}{ }^{39}$. This indicates that $\mathrm{MoO}_{3}$ is strongly dispersed on the surface of $\mathrm{ZrO}_{2}$ wherein peak at $\sim 1118 \mathrm{~cm}^{-1}$ gets disappeared. 

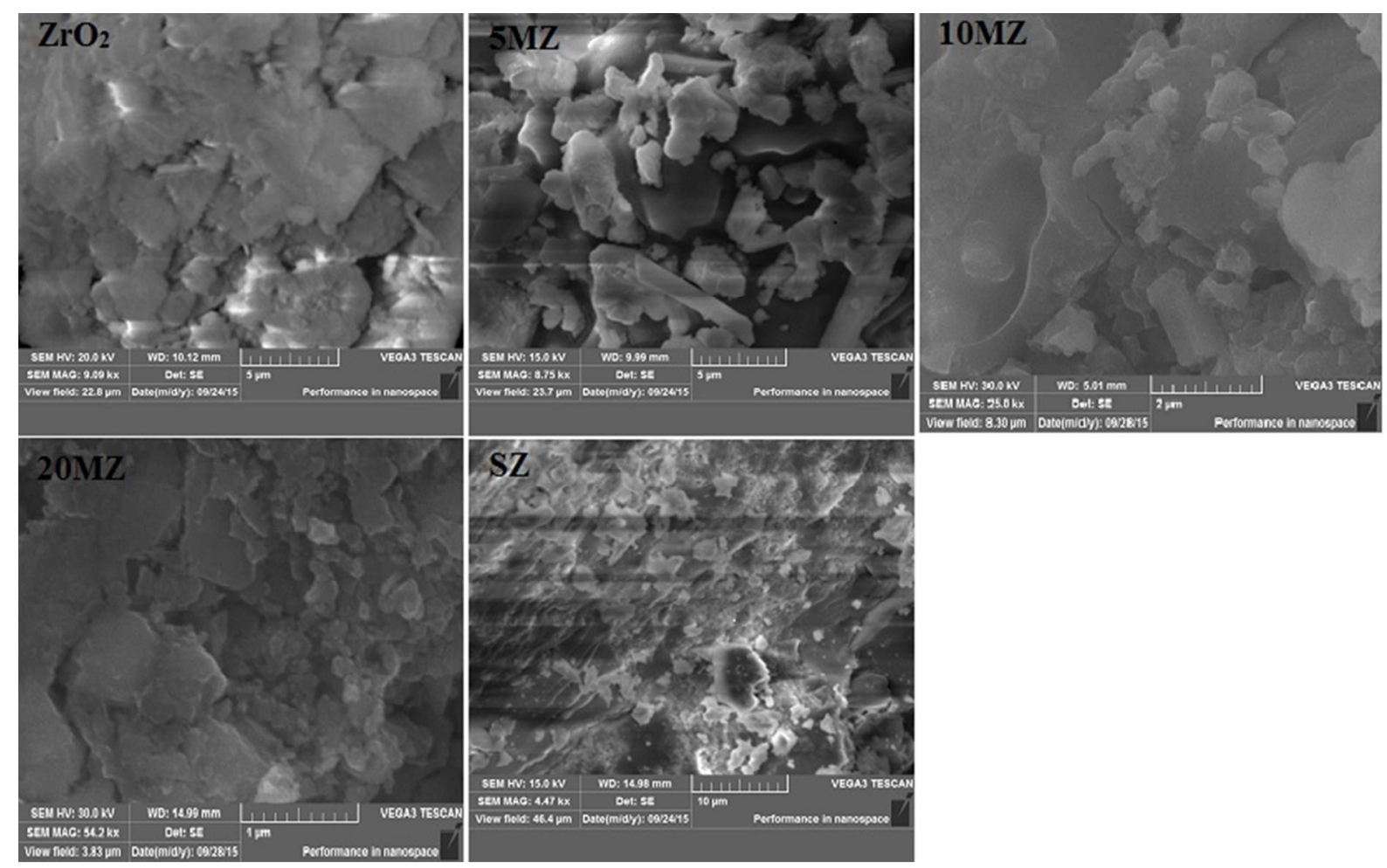

Figure 3. SEM images of $\mathrm{ZrO}_{2}, 5 \mathrm{MZ}, 10 \mathrm{MZ}, 20 \mathrm{MZ}$ and $\mathrm{SZ}$.

SEM micrographs of all the prepared catalysts are presented in Fig. 3. All catalysts having irregular edge shaped particles with variable sizes. In micrometer range, the surface of all the samples appears to be very porous and some aggregates formed by very small particles and no agglomerates are found in all the prepared catalysts, which shows good compatibility with poly matrix. 

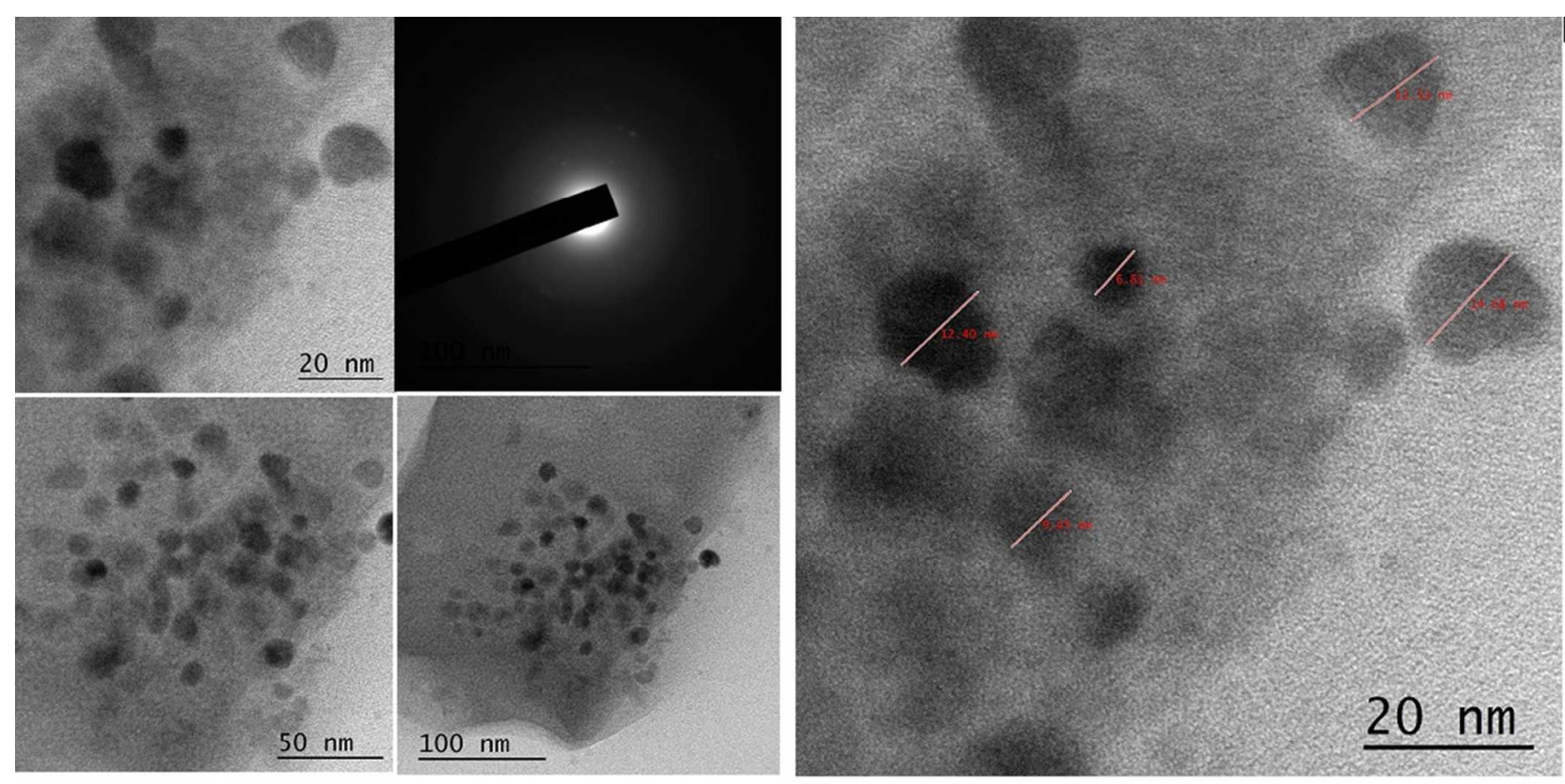

Figur 4. TEM images of SZ nanoparticles (FFT pattern is shown in the inset).

The transmission electron microscopic (TEM) image of SZ nanoparticles is shown in Fig.

4. As seen from the figure, the nanoparticles are composed of spherical particles of dimension in the range of about 6-15 $\mathrm{nm}$. The boundary between the particles (low contrast) was not detectable in the TEM of the SZ which may be due to the interaction between the neighbouring particles. Further, from TEM images, black spots are uniformly distributed throughout the sample and this can be attributed to the presence of SZ nanoparticles.

The ICP-OES results indicates that $5 \mathrm{MZ}, 10 \mathrm{MZ}$ and $20 \mathrm{MZ}$ consisted of $4.96 \%, 9.87 \%$ and $20.04 \%$ of $\mathrm{Mo}(\mathrm{VI})$ respectively.

\subsection{Catalytic activity studies of solid acids (in esterification)}

To begin with, in order to optimize the reaction conditions, liquid phase esterification reactions between 3-fluoro benzoic acid (3FBA) and n-propanol (PrOH) over the solid acids 
such as $\mathrm{ZrO}_{2}, 5 \mathrm{MZ}, 10 \mathrm{MZ}, 20 \mathrm{MZ}$ and $\mathrm{SZ}$ catalysts, as well as homogeneous Brönsted acids such pTsOH and $\mathrm{H}_{2} \mathrm{SO}_{4}$ were carried out (Scheme 1). In general, all the solid acids used in the present work were active in this reaction. In the absence of any solid acid catalyst negligible amount $(5.3 \%)$ of the esterified product was observed. This indicates that the esterification is a catalyzed reaction.

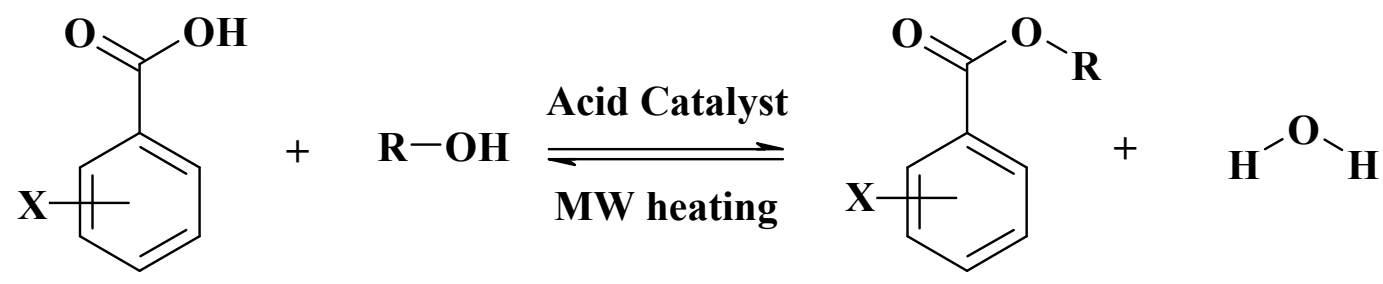

where, $\mathrm{X}=\mathrm{F}, \mathrm{Cl}, \mathrm{Br}$ and $\mathrm{I} ; \mathrm{R}=n$-propyl and iso-propyl group.

Scheme 1. Esterification of halogenated aromatic carboxylic acids with propanol in presence of $\mathrm{ZrO}_{2}, \mathrm{MZ}, \mathrm{SZ}, \mathrm{pTsOH}$ and $\mathrm{H}_{2} \mathrm{SO}_{4}$ acid catalysts.

In order to obtain highest possible yield of the reaction product, esterification of 3FBA with $\mathrm{PrOH}$ was carried out and optimized by varying reaction parameters such as, nature of solid acids, reaction time, reaction temperature, molar-ratio of the reactants (3FBA:PrOH) and weight of the solid acid catalyst.

\subsubsection{Effect of nature of solid acids on the yield of P3FB}

To find out a facile catalytic material, esterification of 3FBA with $\mathrm{PrOH}$ was carried out in presence $0.05 \mathrm{~g}$ of different solid acids such as $\mathrm{ZrO}_{2}, 5 \mathrm{MZ}, 10 \mathrm{MZ}, 20 \mathrm{MZ}$ and $\mathrm{SZ}$ and compared with homogeneous Brönsted acids namely $\mathrm{H}_{2} \mathrm{SO}_{4}$ and p-toluenesulfonic acid $(\mathrm{pTsOH})$. The reactions were carried out at $130{ }^{\circ} \mathrm{C}$ for $30 \mathrm{~min}$ and the results are presented in the Fig. 5. The catalytic activity was found to be significantly influenced by the dispersion of $\mathrm{Mo}(\mathrm{VI})$ or $\mathrm{SO}_{4}{ }^{2-}$ ions on $\mathrm{ZrO}_{2}$. The yield of desired reaction product i.e., propyl 3-fluoro 
benzoate $(\mathrm{P} 3 \mathrm{FB})$ over different solid acid catalysts was found to be in the order: $\mathrm{H}_{2} \mathrm{SO}_{4} \approx \mathrm{p}$ -

$\mathrm{TsOH} \approx \mathrm{SZ}>10 \mathrm{MZ}>20 \mathrm{MZ}>5 \mathrm{MZ}>\mathrm{ZrO}_{2}$

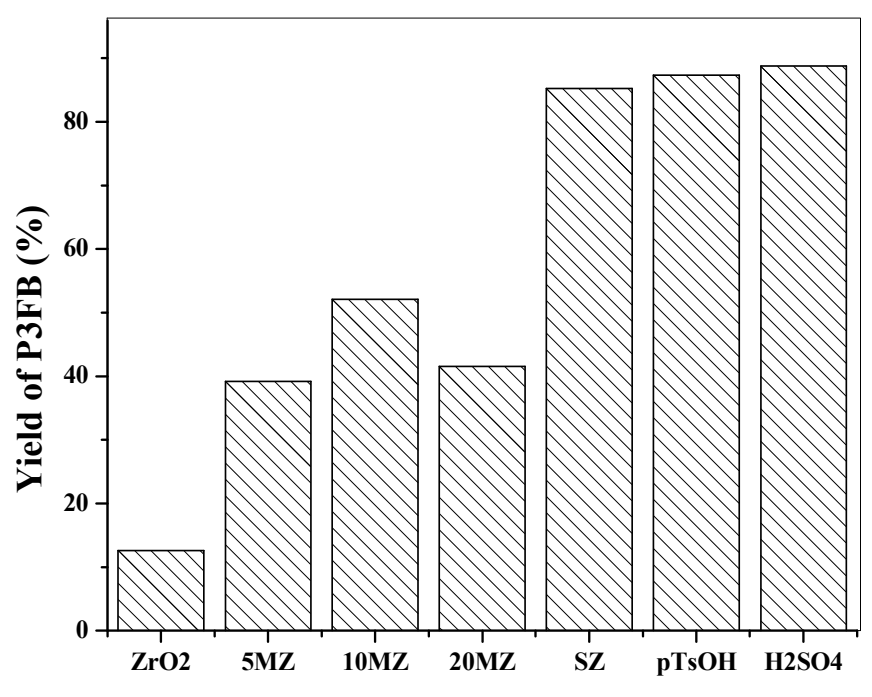

Acid catalysts

Figure 5. Effect of nature of catalyst on esterification of 3FBA with $\mathrm{PrOH}$. [Reaction conditions: $0.05 \mathrm{~g}$ of catalyst at $130{ }^{\circ} \mathrm{C}$ for $30 \mathrm{~min}$ under $\mathrm{MW}$ irradiation, $3 \mathrm{FBA}=0.5 \mathrm{~g}$ and $\mathrm{PrOH}=2.7$ $\mathrm{mL}]$.

Among all the solid acids, SZ showed highest yield of (propyl 3-fluro benzoate) P3FB ester, which can be due to the presence of 'strong' and 'very strong' acidic sites in SZ. However, $\mathrm{MZ}$ catalysts showed poor yield of $\mathrm{P} 3 \mathrm{FB}$ compared to SZ which can be due to the presence of 'moderate' and 'strong' acid sites in MZ. This clearly indicates that the esterification of aromatic carboxylic acid with an alcohol is highly influenced by the strength of acid sites on the catalyst. Homogeneous Brönsted acids $\left(\mathrm{H}_{2} \mathrm{SO}_{4}\right.$ or $\left.\mathrm{pTsOH}\right)$ showed comparatively higher yield than other solid acids in the present study. However, use of eco-friendly heterogeneous catalysts is advantageous over homogeneous acids due to easy separation and re-usability. Under the present reaction conditions, the catalytic activity of SZ was comparable to the catalytic activity of a 
conventional homogeneous Brönsted acids and this clearly demonstrates that the efficiency of SZ heterogeneous catalyst is suitable for the replacement for homogeneous catalysts such as sulfuric acid or $\mathrm{pTsOH}$.

$\mathrm{SZ}$ and $\mathrm{pTsOH}$ were selected as catalysts for further optimization of reaction conditions and for kinetic study.

Further, the yield of P3FB was found to increase over different solid acids in the order: $\mathrm{ZrO} 2<5 \mathrm{MZ}<20 \mathrm{MZ}<10 \mathrm{MZ}<\mathrm{SZ}$. This order clearly indicates that, there is correlation between the catalytic activity and their physic-chemical properties like surface area, total surface acidity and tetragonal phase of the catalyst.

\subsubsection{Effect of MW irradiation on the yield of P3FB}

In order to study the effect of MW irradiation on the yield of P3FB, esterification of 3FBA with PrOH was carried out with and without MW irradiation and the results are given in table $2 \mathrm{a}$ and $2 \mathrm{~b}$. The reactions were carried out at different reaction times (10-70 min) and also by varying reaction temperature $\left(90-130^{\circ} \mathrm{C}\right)$. It was observed that the yield of P3FB was higher in the reactions were carried out in presence of MW irradiation when compared to the yield of P3FB obtained without MW irradiation (thermal conventional method). A maximum yield of P3FB (98.5\%) was obtained at $130{ }^{\circ} \mathrm{C}$ when the reaction was carried out for 60 min under MW irradiation.

However, A maximum yield of P3FB $(38.7 \%)$ was obtained at $130{ }^{\circ} \mathrm{C}$ when the reaction was carried out for 60 min without MW irradiation.

This study indicates that the esterification reaction under MW irradiation is much more effective than the conventional thermal method. 


\begin{tabular}{|c|c|c|c|c|c|c|c|}
\hline \multirow{2}{*}{ SZ } & \multicolumn{7}{|c|}{ Time (min) } \\
\cline { 2 - 8 } catalyst & 10 & 20 & 30 & 40 & 50 & 60 & 70 \\
\hline Yield of & 38.4 & 69.5 & 85.2 & 93.6 & 97.3 & 98.5 & 98.4 \\
P3FB (\%) & $(4.3)$ & $(8.1)$ & $(15.3)$ & $(21.5)$ & $(25.8)$ & $(29.9)$ & $(35.4)$ \\
\hline
\end{tabular}

Table 2a. Effect of MW irradiation and reaction time on esterification of 3FBA with PrOH. [Reaction conditions: $0.05 \mathrm{~g}$ of catalyst at $130^{\circ} \mathrm{C}, 3 \mathrm{FBA}=0.5 \mathrm{~g}, \mathrm{PrOH}=2.7 \mathrm{~mL}$ ].

\begin{tabular}{|c|c|c|c|c|c|}
\hline \multirow{2}{*}{ SZ } & \multicolumn{5}{|c|}{ Temperature $\left({ }^{\circ} \mathrm{C}\right)$} \\
\cline { 2 - 6 } & 90 & 100 & 110 & 120 & 130 \\
\hline Yield of & $59.1(9.8)$ & $76.8(15.4)$ & $87.1(22.5)$ & $92.3(26.7)$ & $98.5(38.7)$ \\
P3FB (\%) & & & & & \\
\hline
\end{tabular}

Table 2b. Effect of MW irradiation and reaction temperature on esterification of 3FBA with PrOH. [Reaction conditions: $0.05 \mathrm{~g}$ of catalyst for $60 \mathrm{~min}, 3 \mathrm{FBA}=0.5 \mathrm{~g}$ and $\mathrm{PrOH}=2.7 \mathrm{~mL}$ ].

Note: The yield of P3FB by thermal conventional method are shown in the parenthesis.

\subsubsection{Effect of reaction time on the yield of P3FB}

In order to study the effect of reaction time on the yield of the P3FB, the esterification reactions of $0.5 \mathrm{~g}$ of 3FBA with $2.7 \mathrm{~mL} \mathrm{PrOH}$ were carried out in the time range of 10-70 min over $0.05 \mathrm{~g}$ of catalyst at $130{ }^{\circ} \mathrm{C}$ and the results are given in Fig. 6. It was observed that the yield 
$(\%)$ of P3FB increases with an increase in the reaction time and a maximum yield was observed at $60 \mathrm{~min}$ and stabilizes thereafter over both $\mathrm{SZ}$ and pTsOH catalysts. Hence, reaction time of 60 min was chosen to optimize the other reaction conditions.

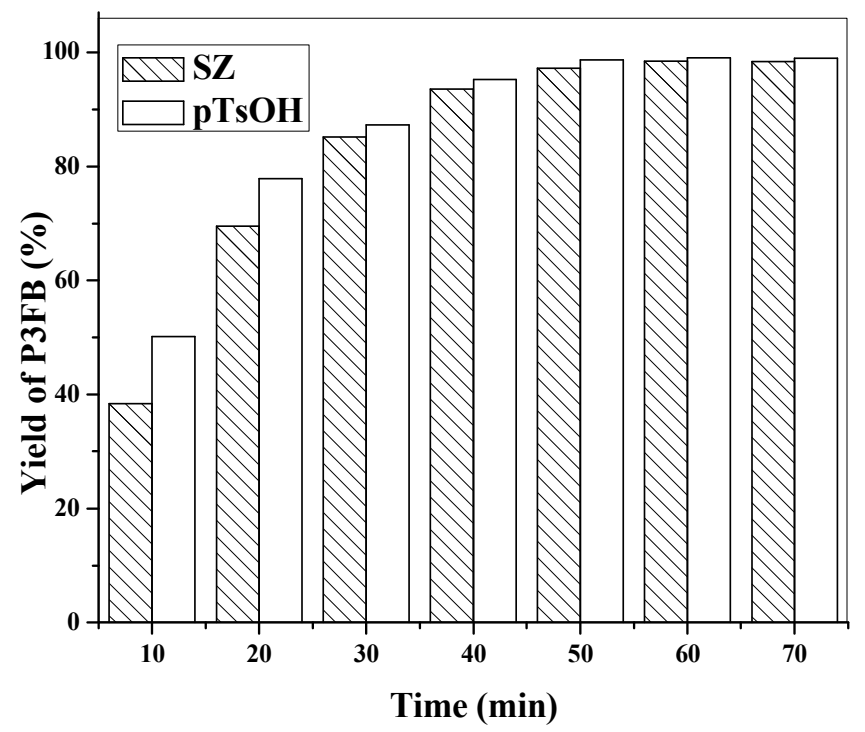

Figure 6. Effect of reaction time on esterification of 3FBA with PrOH. [Reaction conditions: $0.05 \mathrm{~g}$ of catalyst at $130^{\circ} \mathrm{C}$ under MW irradiation, $\left.3 \mathrm{FBA}=0.5 \mathrm{~g}, \mathrm{PrOH}=2.7 \mathrm{~mL}\right]$.

\subsubsection{Effect of reaction temperature on the yield of P3FB}

The esterification reactions of 3FBA with $\mathrm{PrOH}$ were carried out in a temperature range of $85-145^{\circ} \mathrm{C}$ over $\mathrm{SZ}$ and $\mathrm{pTsOH}$ for $60 \mathrm{~min}$ and the results are shown in Fig. 7. The results clearly indicate that the yield $(\%)$ of $\mathrm{P} 3 \mathrm{FB}$ increases with an increase in the reaction temperature and $130{ }^{\circ} \mathrm{C}$ was found to be an optimized reaction temperature for the current reaction. The yield of ester was stabilized when the temperature was increased beyond $130{ }^{\circ} \mathrm{C}$. This may be due to the fact that shorter reaction time requires higher temperature to obtain highest possible yield of ester. Therefore, $130{ }^{\circ} \mathrm{C}$ was chosen as the optimum reaction temperature to obtain highest possible yield (\%) of $\mathrm{P} 3 \mathrm{FB}$ ester. 


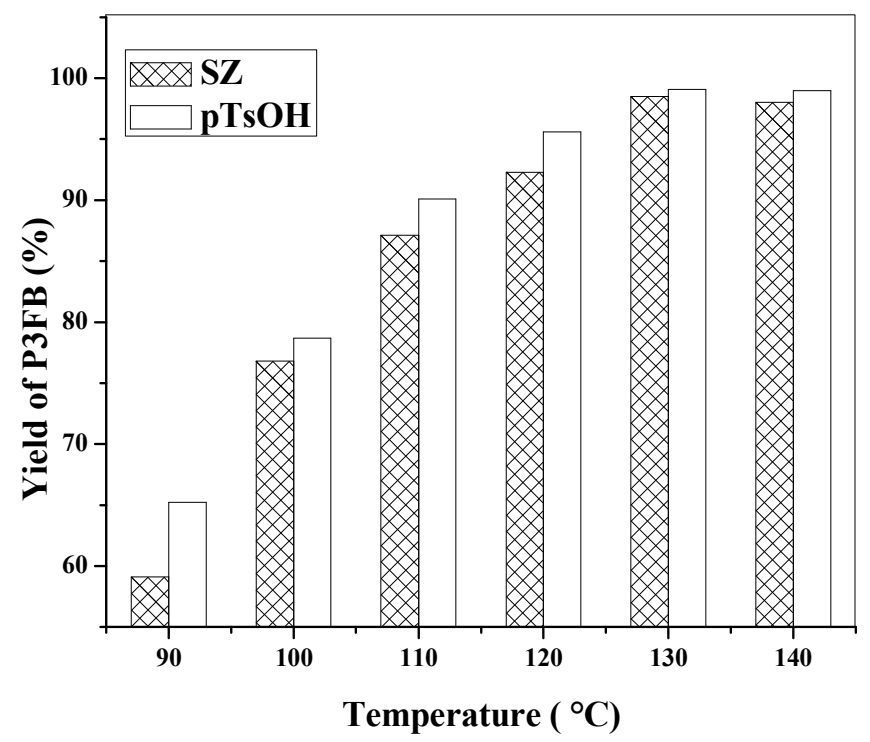

Figure 7. Effect of reaction temperature on esterification of 3FBA with $\mathrm{PrOH}$. [Reaction conditions: $0.05 \mathrm{~g}$ of catalyst for $60 \mathrm{~min}$ under $\mathrm{MW}$ irradiation, $3 \mathrm{FBA}=0.5 \mathrm{~g}$ and $\mathrm{PrOH}=2.7$ $\mathrm{mL}]$.

\subsubsection{Effect of molar ratio of the reactants (3FBA:PrOH) on the yield of P3FB}

In order to study the effect of molar ratio of the reactants i.e., 3FBA to PrOH, esterification was carried out at different molar ratios ranging from 1:5 to 1:20 over SZ and pTsOH catalysts and the results are shown in Fig. 8. The yield of P3FB increases with an increase in the molar ratio of 3FBA to $\mathrm{PrOH}$ from 1:5 to 1:10. But when the molar ratio was increased beyond 1:10, the yield of desired ester was found to decrease. The reason can be attributed as follows:

Theoretically, esterification reaction requires one mole of alcohol for one mole of carboxylic acid; however, in practice, higher amount of alcohol acts as a solvent as well as it may shift the equilibrium to the right side (Scheme 1) resulting in the formation of the ester. In the present study, alcohol $(\mathrm{PrOH})$ acts both as a reactant as well as a solvent. Higher molar ratio of PrOH 
(more than 10 molar ratio) decreased the yield of ester due to solvent effect of propanol. Hence, 1:10 molar ratio of 3FBA to PrOH was chosen for further optimization of reaction conditions.

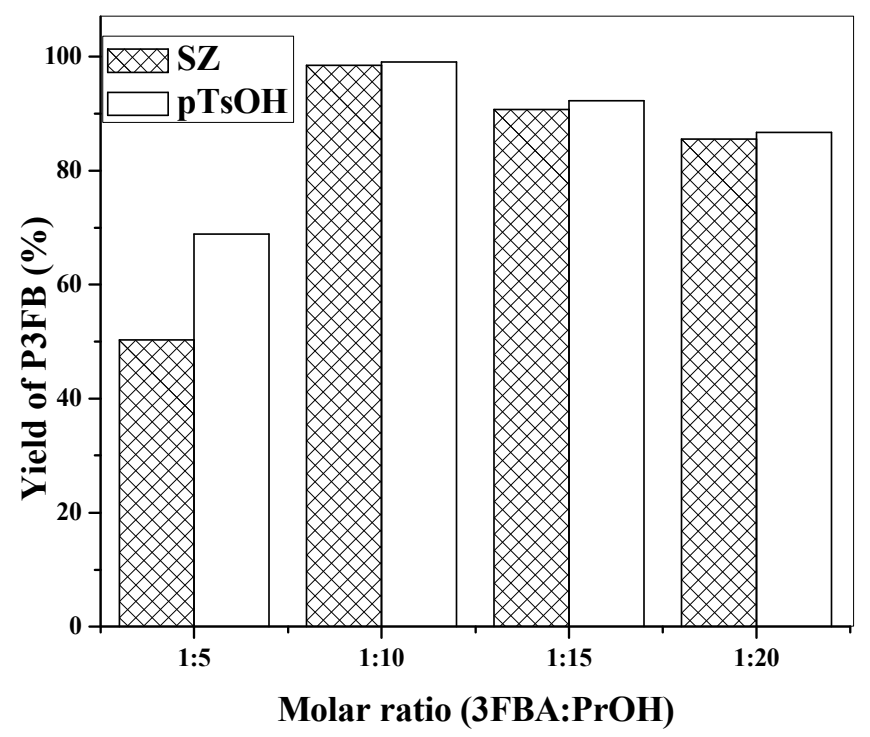

Figure 8. Effect of molar ratio of reactans on esterification of 3FBA with PrOH. [Reaction conditions: $0.05 \mathrm{~g}$ of catalyst at $130{ }^{\circ} \mathrm{C}$ for 60 min under $\mathrm{MW}$ irradiation and $\left.3 \mathrm{FBA}=0.5 \mathrm{~g}\right]$.

\subsubsection{Effect of amount of solid acid on the yield of P3FB}

The effect of amount of SZ or pTsOH in esterification reaction was studied at $130{ }^{\circ} \mathrm{C}$ by using 3FBA to PrOH molar ratio of 1:10 and the results are shown in Fig. 9. The yield (\%) of P3FB increases when the weight of the catalyst was increased from $0.02 \mathrm{~g}$ to $0.05 \mathrm{~g}$ and an excellent yield of P3FB was achieved over $0.05 \mathrm{~g}$ of SZ catalyst. Further, an increase in the weight of SZ catalyst beyond $0.05 \mathrm{~g}$ stabilizes the yield of the ester. 


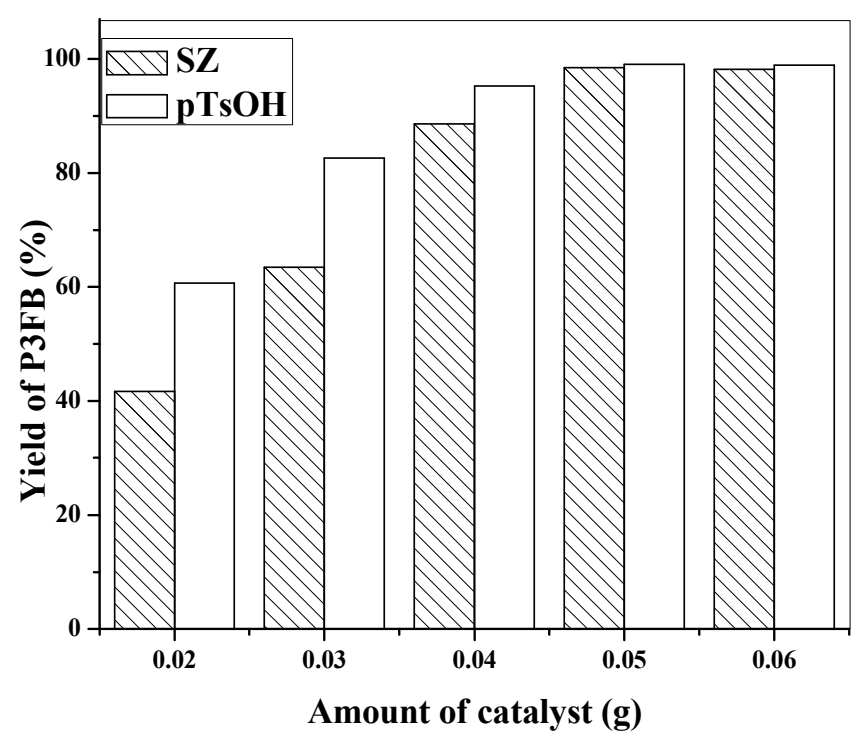

Figure 9. Effect of amount of catalyst on esterification of 3FBA with PrOH. [Reaction conditions: temperature at $130{ }^{\circ} \mathrm{C}$ for 60 min usnder $\mathrm{MW}$ irradiation, $3 \mathrm{FBA}=0.5 \mathrm{~g}$ and $\mathrm{PrOH}=$ $2.7 \mathrm{~mL}]$.

\subsection{Kinetic studies}

The kinetic studies were carried out over SZ and pTsOH catalysts. The kinetic study experiments were conducted to obtain temperature coefficient and energy of activation of SZ with pTsOH and mass transfer limitations during esterification of 3FBA with PrOH. The mass transfer limitation was evaluated by changing the amount of catalytic material. A linear increase in the yield of P3FB with an increase in the catalytic material was observed (Fig. 9). This shows that the resistance to mass transfer is negligibly small between the liquid bulk of reactant and the other outer surface of the catalytic materials. In fact in the absence of all transport limitations, the rate of reaction is proportional to the amount of catalytic materials ${ }^{40}$.

Plot of $-\ln \left[1-y i e l d_{\mathrm{P} 3 \mathrm{FB}}\right]$ against reaction time with varying the reaction temperature from $110^{\circ} \mathrm{C}$ to $130^{\circ} \mathrm{C}$ over SZ and pTsOH are shown in Fig. 10. 

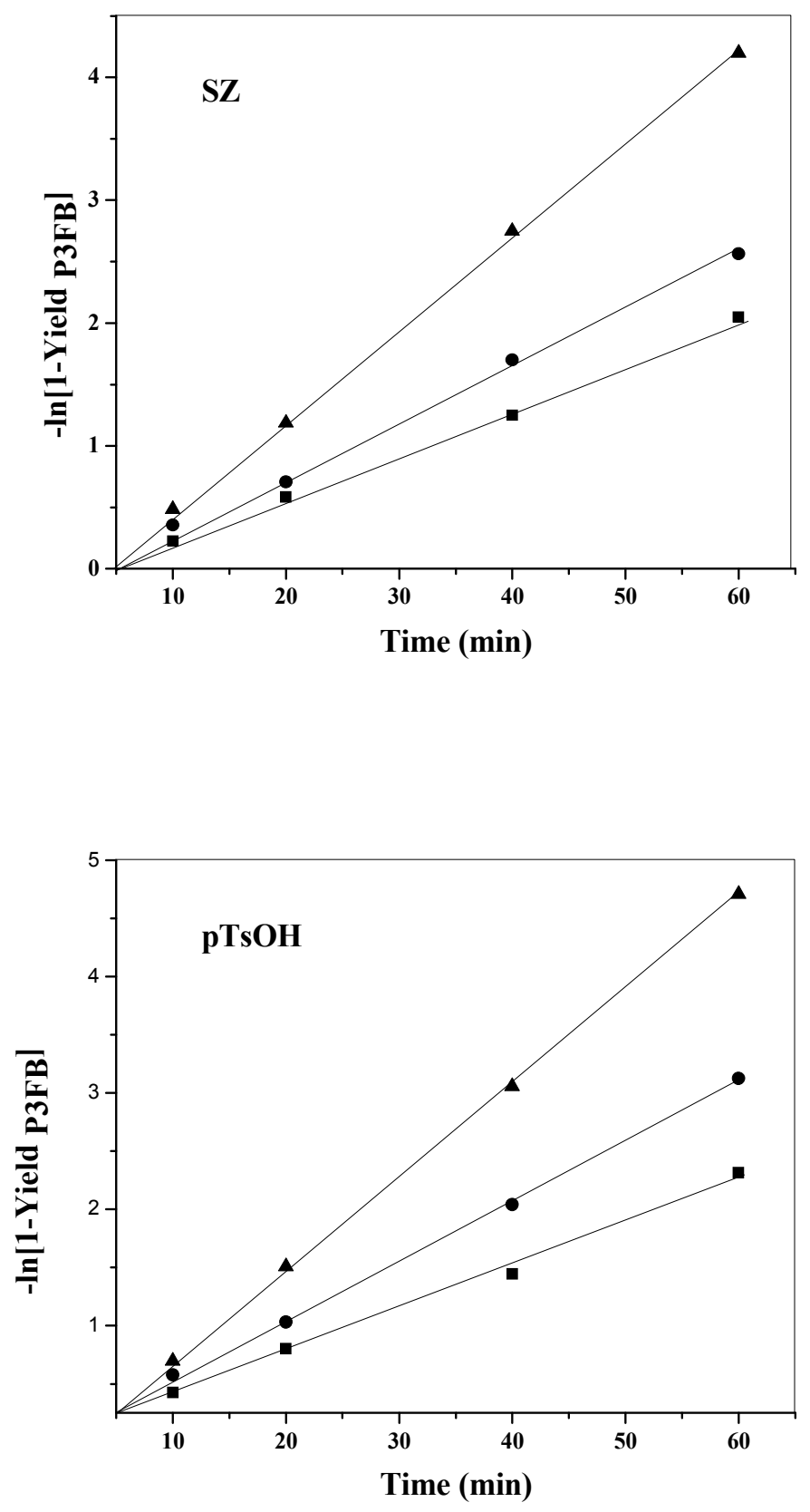

Figure 10. Plot of first-order equation for the formation of $\mathrm{P} 3 \mathrm{FB}$ over $\mathrm{SZ}$ and $\mathrm{pTsOH}$ at $\mathbf{\square -} 110$ ${ }^{\circ} \mathrm{C}$, •- $120{ }^{\circ} \mathrm{C}$ and $\boldsymbol{\Delta}-130{ }^{\circ} \mathrm{C}$.

The values of first-order rate constants for $\mathrm{SZ}$ and $\mathrm{pTsOH}$ at different reaction temperatures are obtained from slopes of plots (Fig. 10). The values of energy of activation 
calculated from Arrhenius equation and the temperature coefficient calculated using equations 1 and 2 respectively and values are given in Table 3. Among SZ and pTsOH catalysts, SZ (66.82 $\mathrm{KJmol}^{-1}$ ) was slightly higher energy of activation than pTsOHand (58.93 $\left.\mathrm{KJmol}^{-1}\right)$. This clearly indicates that SZ catalyst has comparable activity and can easily replace homogeneous pTsOH Brönsted acid catalyst.

$$
\begin{aligned}
& E a=2.303 R \log \left(\frac{k 2}{k 1}\right)\left[\frac{T 1 \times T 2}{T 2-T 1}\right] \quad---\quad \text { Eq. (1) } \\
& \text { Temperature coefficient }=\left(\frac{k 2}{k 1}\right) \quad \text {---- Eq. (2) }
\end{aligned}
$$

where, $\mathrm{R}=$ gas constant, $\mathrm{k}_{1}=$ rate constant at temperature $\mathrm{T}_{1}$ and $\mathrm{k}_{2}=$ rate constant at temperature $\mathrm{T}_{2}$

Table 3. Reaction rate constant, energy of activation and temperature coefficients for the

\begin{tabular}{|c|c|c|c|c|}
\hline \multirow[t]{2}{*}{ Catalyst } & \multicolumn{2}{|c|}{$\begin{array}{c}\text { Rate constant for } \\
\text { formation of P3FB }\left(10^{-3}\right. \\
\left.\min ^{-1}\right)\end{array}$} & \multirow{2}{*}{$\begin{array}{c}\text { Energy of activation } \\
\text { (Ea) for the formation } \\
\text { of P3FB } \\
\left(\mathrm{KJ} \mathrm{mol}^{-1}\right)\end{array}$} & \multirow[t]{2}{*}{$\begin{array}{l}\text { Temperature co- } \\
\text { efficient }\left(k_{2} / k_{1}\right)\end{array}$} \\
\hline & $120^{\circ} \mathrm{C}$ & $130^{\circ} \mathrm{C}$ & & \\
\hline $\mathrm{SZ}$ & 45.06 & 74.84 & 66.82 & 1.66 \\
\hline pTsOH & 51.10 & 79.94 & 58.93 & 1.56 \\
\hline
\end{tabular}
formation of P3FB of SZ and pTsOH catalysts for esterification of 3FBA with PrOH.

\subsection{Effect of reactant pre-adsorption}

In order to study the catalytic reaction mechanism of esterification of 3FBA with PrOH, reactant pre-adsorption study was carried out ${ }^{41}$. The important mechanistic question in esterification catalyzed by solid acid catalyst is the involvement of one or two surface-bonded 
species corresponding to either Eley-Rideal (ER) or Langmuir-Hinshelwood (LH) type mechanism. The ER mechanism involves the adsorption of only one of the reactants (either 3FBA or $\mathrm{PrOH}$ ) onto the surface, after which the other reactant interacts with the adsorbed species directly followed by desorption of the reaction product ${ }^{42}$. In case of LH mechanism, both reactants (3FBA and $\mathrm{PrOH})$ first adsorb onto the surface before reaction could take place ${ }^{43}$. Thus, the effect of reactant pre-adsorption has been studied under optimized reaction conditions such as $0.05 \mathrm{~g}$ of SZ at $130{ }^{\circ} \mathrm{C}$ for 30 min under MW irradiation with $0.5 \mathrm{~g}$ of $3 \mathrm{FBA}$ and $2.7 \mathrm{~mL}$ of $\mathrm{PrOH}$. $0.05 \mathrm{~g}$ of $\mathrm{SZ}$ was premixed with $\mathrm{PrOH}$ or both 3FBA and $\mathrm{PrOH}$ for $24 \mathrm{~h}$ at room temperature and the reaction was performed under optimized reaction conditions after adding remaining reactants. The obtained yield of P3FB verses time plots are shown in Fig. 11, where the plot corresponding to without premixing of reactants is also presented for comparison. Premixing study of the catalyst with 3FBA was not carried out because of its solid nature and literature results revealed that the chemisorption of an alcohol is stronger than the acid ${ }^{44}$.

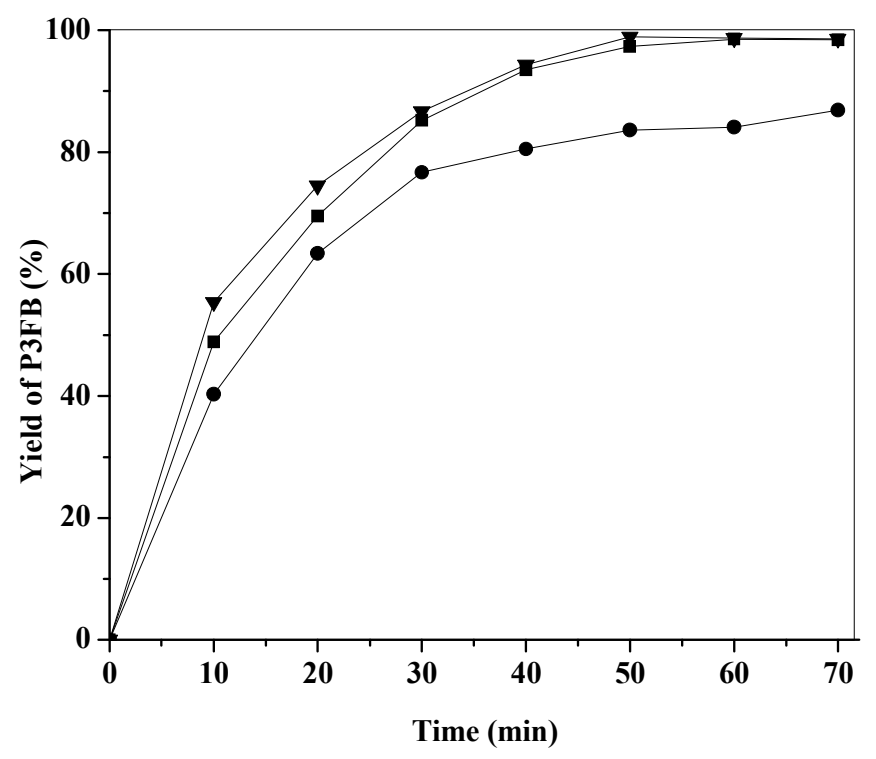


Figure 11. Effect of reactant pre-adsorption on catalyst on esterification of 3FBA with PrOH. [Reaction conditions: $0.05 \mathrm{~g}$ of $\mathrm{SZ}$ at $130{ }^{\circ} \mathrm{C}$ for $60 \mathrm{~min}$ under $\mathrm{MW}$ irradiation, 3FBA $=0.5 \mathrm{~g}$ and $\mathrm{PrOH}=2.7 \mathrm{~mL} . .(\bullet)$ pre-adsorption of $\mathrm{PrOH},(\boldsymbol{\bullet})$ no pre-adsorption of reactants and $(\mathbf{\Delta})$ pre-adsorption of both 3FBA and PrOH.

It can be observed that the highest yield of P3FB was obtained when the catalyst was premixed with both 3FBA and $\mathrm{PrOH}$ where as lowest yield was obtained when premixed with $\mathrm{PrOH}$ and moderate yield was obtained under non-premixing condition of reactant with the catalyst. The results in Fig. 11 suggest that the reaction needs chemisorption of both 3FBA and PrOH involving LH type mechanism.

A probable LR type mechanism for an acid catalyzed esterification of aromatic carboxylic acids with aliphatic alcohols is shown in the Scheme 2. It is possible that an alcohol and an aromatic carboxylic acid are preferentially adsorbed on the Bronsted acid sites of modified zirconia during esterification. The hydroxyl group of alcohol is protonated by Brönsted acid on the solid acid catalyst surface while the carboxylic acid on an adjacent site leading to the formation of carbocation ('A' in Scheme 2). Deprotonation of alcoholic oxygen produces a nucleophile, which attacks the carbocation to generate a tetrahedral intermediate ('B' in Scheme 2). The tetrahedral intermediate eliminates water to produce an ester ${ }^{45-46}$. 


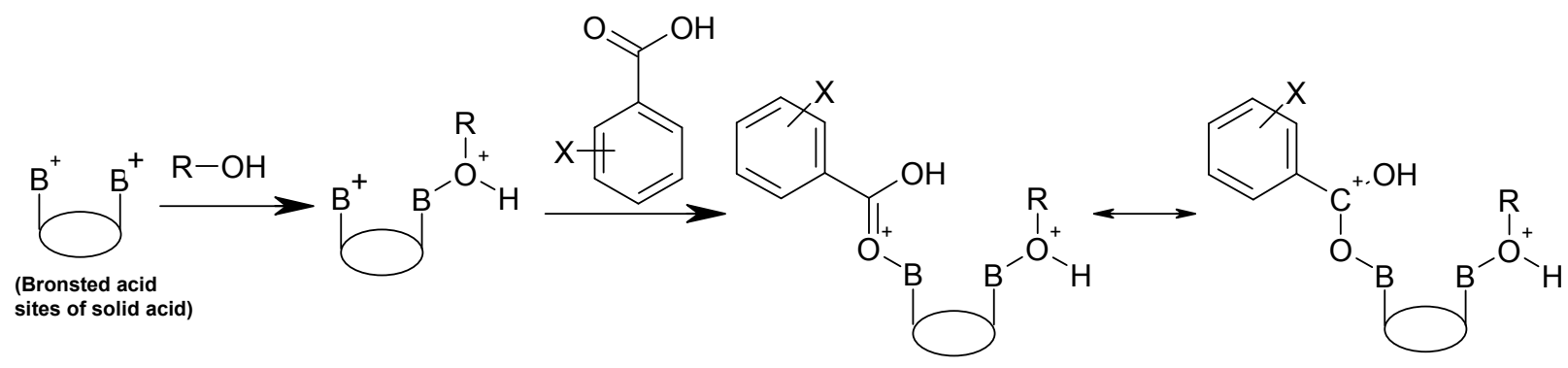

(A)

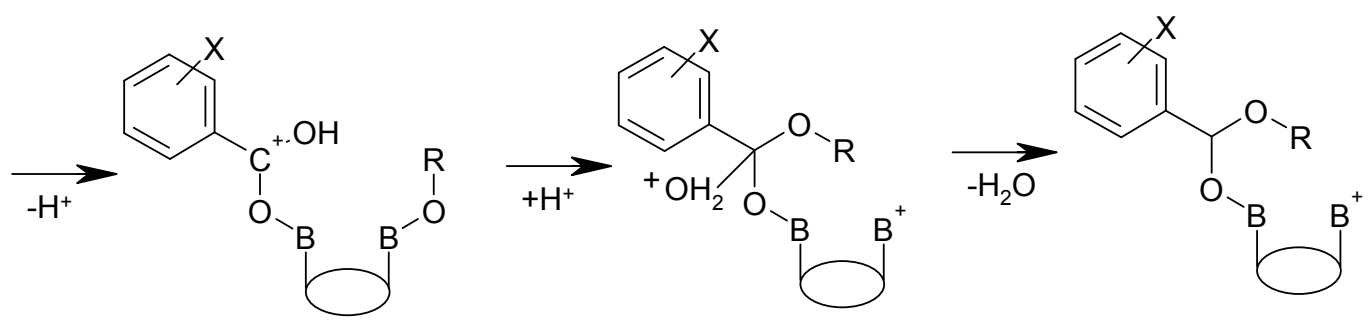

(B)

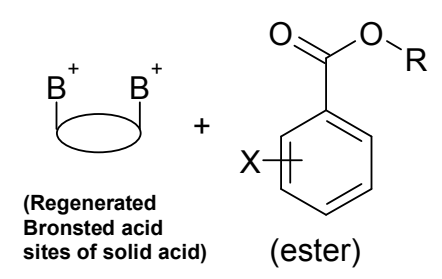

Scheme 2. Probable mechanism for an acid catalyzed esterification of a carboxylic acid with an alcohol over Brönsted acid sites of acid catalysts.

\subsubsection{Esterification of various halogenated aromatic carboxylic acid with propanol under optimized reaction conditions}

Esterification of various halogenated aromatic carboxylic acids with propanol were carried out in the molar ratio of carboxylic acid : propanol $=1: 10$ over $0.05 \mathrm{~g}$ of SZ at $130{ }^{\circ} \mathrm{C}$ and the results are presented in Table 4. Spectral data of the synthesized esters are given in Appendix-1.

Table 4. List of halogenated aromatic carboxylic acids, alcohols, reaction time, products and yield of products. 


\begin{tabular}{|c|c|c|c|c|c|}
\hline Entry & Carboxylic acids & Alcohols & $\begin{array}{l}\text { Time } \\
\text { (min) }\end{array}$ & Esterified product & $\begin{array}{c}\text { Yield (\%) of } \\
\text { esterified } \\
\text { product }\end{array}$ \\
\hline 1 & $\mathrm{OH}$ & n-propnol & 60 & $\mathbf{O}$ & 93.5 \\
\hline 2 & $\mathbf{O H}$ & n-propnol & 60 & & 83.6 \\
\hline 3 & $\mathbf{O H}$ & n-propnol & 60 & & 81.5 \\
\hline 4 & & n-propnol & 60 & & 98.5 \\
\hline 5 & OH & Iso & 60 & $\mathbf{O}_{-}$ & 79.6 \\
\hline
\end{tabular}




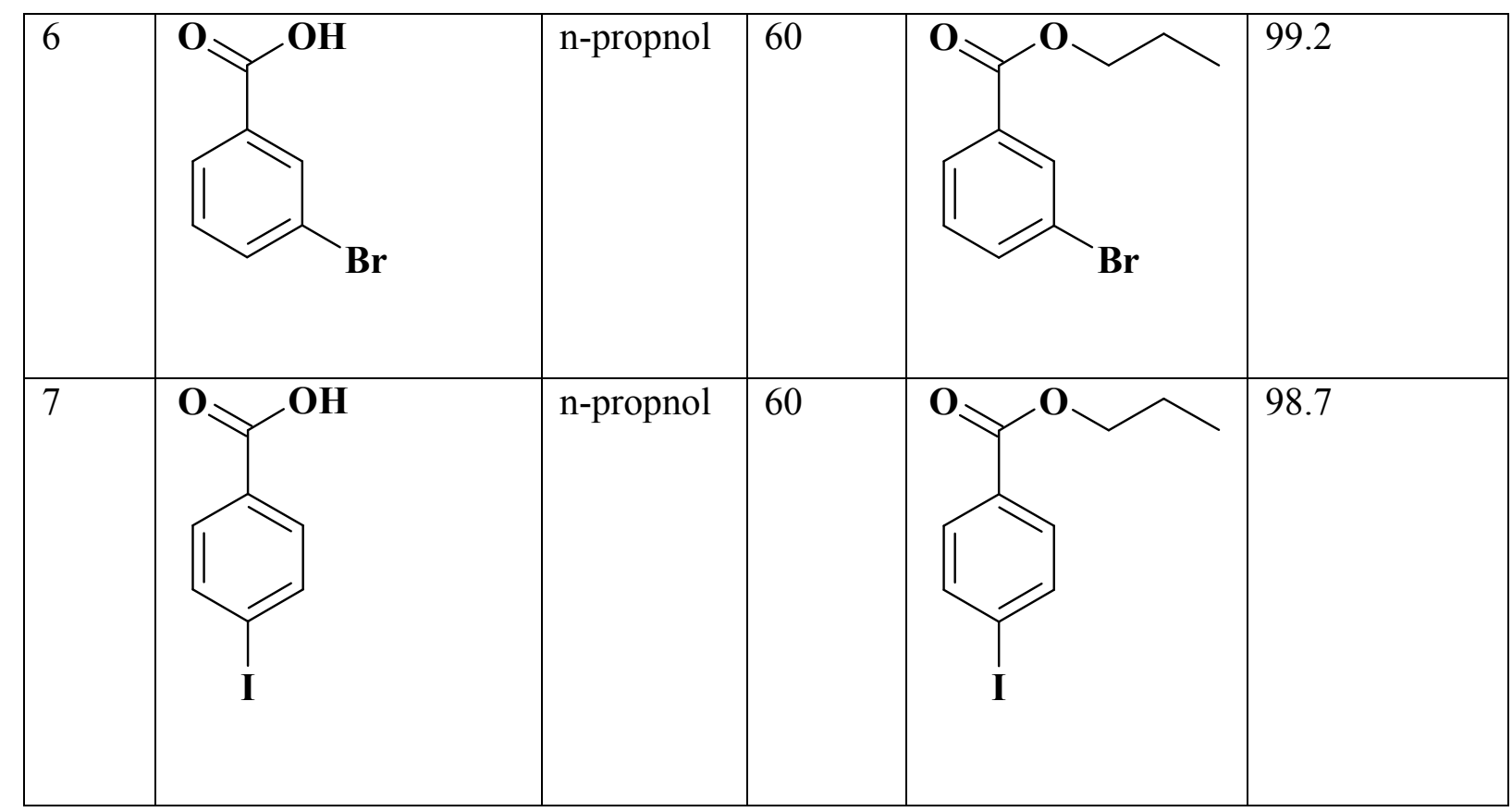

[Reaction conditions: reaction temperature $=130^{\circ} \mathrm{C}$, catalyst weight $=0.05 \mathrm{~g}$ of SZ, $1: 10$ (carboxylic acid: alcohol).

\section{$\underline{\text { Appendix - 1 }}$}

\section{Spectral data of synthesized esters (Refer to table 4)}

Propyl 2-chloro benzoate (Table 4, Entry 1): ${ }^{1} \mathrm{H}$ NMR $\left(\mathrm{CDCl}_{3}, 400 \mathrm{~Hz}\right): \delta(\mathrm{ppm}) 1.041(\mathrm{t}$, $3 \mathrm{H}, J=7.6 \mathrm{~Hz}), 1.801$ (sextate, 2H, $J=7.6 \mathrm{~Hz}), 4.308$ (t, 2H, $J=6.4 \mathrm{~Hz}), 7.311$ (t, 1H, $J=8.0 \mathrm{~Hz}$ ), 7.385-7.461 (m, 2H), $7.816(\mathrm{~d}, 1 \mathrm{H}, J=7.2 \mathrm{~Hz}) ; 13 \mathrm{C} \mathrm{NMR}\left(\mathrm{CDCl}_{3}, 400 \mathrm{~Hz}\right): \delta(\mathrm{ppm}) 10.524$, $21.990,67.149,126.494,130.585,130.980,131.259,133.312$, 133.552, 165.827; Calculated for $\mathrm{C}_{10} \mathrm{H}_{11} \mathrm{ClO}_{2}$ [m+H. : 199.04, found 199.1; Physical state: Colourless liquid.

Propyl 2-bromo benzoate (Table 4, Entry 2): ${ }^{1} \mathrm{H}$ NMR $\left(\mathrm{CDCl}_{3}, 400 \mathrm{~Hz}\right): \delta(\mathrm{ppm}) 1.043(\mathrm{t}$, $3 \mathrm{H}, J=7.6 \mathrm{~Hz}$ ), 1.807 (sextate, 2H, $J=7.6 \mathrm{~Hz}), 4.308$ (t, 2H, $J=6.4 \mathrm{~Hz}$ ), 7.296-7.379 (m, 2H), $7.757\left(\mathrm{dd}, 1 \mathrm{H}, J_{I}=7.6 \mathrm{~Hz}, J_{2}=2.0 \mathrm{~Hz}\right), 7.780\left(\mathrm{dd}, 1 \mathrm{H}, J_{I}=7.6 \mathrm{~Hz}, J_{2}=2.0 \mathrm{~Hz}\right) ;{ }^{13} \mathrm{H} \mathrm{NMR}\left(\mathrm{CDCl}_{3}\right.$, 
$400 \mathrm{~Hz}): \delta(\mathrm{ppm}) 10.547,21.974,67.234,121.497,127.083,131.166,132.328,132.669$, 134.249, 166.339; Calculated for $\mathrm{C}_{10} \mathrm{H}_{11} \mathrm{BrO}_{2}\left[\mathrm{~m}+\mathrm{H}^{+}\right.$: 242.99, found 243.0; Physical state: Colourless liquid.

Propyl 2-iodo benzoate (Table 4, Entry 3): ${ }^{1} \mathrm{H}$ NMR $\left(\mathrm{CDCl}_{3}, 400 \mathrm{~Hz}\right): \delta(\mathrm{ppm}) 1.043(\mathrm{t}, 3 \mathrm{H}$, $J=7.6 \mathrm{~Hz}), 1.812$ (sextate, $2 \mathrm{H}, J=7.2 \mathrm{~Hz}), 4.304$ (t, 2H, $J=6.4 \mathrm{~Hz}), 7.140$ (t, 1H, $J=7.6 \mathrm{~Hz}), 7.397$ (t, 1H, $J=7.6 \mathrm{~Hz}), 7.787(\mathrm{~d}, 1 \mathrm{H}, J=7.2 \mathrm{~Hz}), 7.986(\mathrm{~d}, 1 \mathrm{H}, J=8.0 \mathrm{~Hz}) ;{ }^{1} \mathrm{H} \mathrm{NMR}\left(\mathrm{CDCl}_{3}, 400 \mathrm{~Hz}\right): \delta$ (ppm) 10.570, 21.145, 67.273, 93.901, 127.834, 130.786, 132.421, 135.620, 141.214, 166.648;

Calculated for $\mathrm{C}_{10} \mathrm{H}_{11} \mathrm{IO}_{2}\left[\mathrm{~m}+\mathrm{H}^{+}\right.$: 290.98, found 291.0; Physical state: Colourless liquid.

Propyl 3-fluoro benzoate (Table 4, Entry 4): ${ }^{1} \mathrm{H}$ NMR $\left(\mathrm{CDCl}_{3}, 400 \mathrm{~Hz}\right): \delta(\mathrm{ppm}) 1.036(\mathrm{t}$, $3 \mathrm{H}, J=7.2 \mathrm{~Hz}$ ), 1.800 (sextate, 2H, J=7.2 Hz), 4.293 (t, 2H, J=6.4 Hz), 7.229-7.261 (m, 1H), $7.415(\mathrm{q}, 1 \mathrm{H}, J=8.0 \mathrm{~Hz}), 7.723(\mathrm{~d}, 1 \mathrm{H}, J=9.2 \mathrm{~Hz}), 7.842(\mathrm{~d}, 1 \mathrm{H}, J=7.6 \mathrm{~Hz}) ;{ }^{1} \mathrm{H}$ NMR $\left(\mathrm{CDCl}_{3}\right.$, $400 \mathrm{~Hz}): \delta(\mathrm{ppm}) 10.392,22.021,66.839,116.260,116.484,119.661,119.878,125.200$, $125.223,129.849,129.926,132.669,132.746,161.303,163.759,165.463$; Calculated for $\mathrm{C}_{10} \mathrm{H}_{11} \mathrm{FO}_{2}\left[\mathrm{~m}+\mathrm{H}^{+}:\right.$183.07, found 183.1; Physical state: Colourless liquid.

Isopropyl 3-fluoro benzoate (Table 4, Entry 5): ${ }^{1} \mathrm{H} \mathrm{NMR}\left(\mathrm{CDCl}_{3}, 400 \mathrm{~Hz}\right): \delta$ (ppm) 1.375 $(\mathrm{d}, 6 \mathrm{H}, J=6.4 \mathrm{~Hz}), 5.254(\mathrm{~h}, 1 \mathrm{H}, J=6.0 \mathrm{~Hz}), 7.232\left(\mathrm{dd}, 1 \mathrm{H}, J_{I}=8.4 \mathrm{~Hz}, J_{2}=2.0 \mathrm{~Hz}\right), 7.406(\mathrm{q}, 1 \mathrm{H}$, $J=8.0 \mathrm{~Hz}), 7.712(\mathrm{~d}, 1 \mathrm{H}, J=9.2 \mathrm{~Hz}), 7.830(\mathrm{~d}, 1 \mathrm{H}, J=7.6 \mathrm{~Hz}) ;{ }^{1} \mathrm{H} \mathrm{NMR}\left(\mathrm{CDCl}_{3}, 400 \mathrm{~Hz}\right): \delta(\mathrm{ppm})$ $21.843,68.838,116.252,116.477,119.560,119.777,125.177,129.787,129.864,133.087$, 133.164, 161.295, 163.751, 164.921; $\mathrm{C}_{10} \mathrm{H}_{11} \mathrm{FO}_{2}\left[\mathrm{~m}+\mathrm{H}^{+}:\right.$: 183.07, found 183.1; Physical state: Colourless liquid.

Propyl 3-bromo benzoate (Table 4, Entry 6): ${ }^{1} \mathrm{H}$ NMR $\left(\mathrm{CDCl}_{3}, 400 \mathrm{~Hz}\right): \delta(\mathrm{ppm}) 1.032(\mathrm{t}$, $3 \mathrm{H}, J=7.2 \mathrm{~Hz}$ ), 1.797 (sextate, 2H, $J=7.2 \mathrm{~Hz}$ ), 4.287 (t, 2H, J=7.2 Hz), 7.317 (t, 1H, $J=8.0 \mathrm{~Hz}$ ), $7.677(\mathrm{~d}, 1 \mathrm{H}, J=8.0 \mathrm{~Hz}), 7.976(\mathrm{~d}, 1 \mathrm{H}, J=7.2 \mathrm{~Hz}), 8.175(\mathrm{~s}, 1 \mathrm{H}) ;{ }^{1} \mathrm{H}$ NMR $\left(\mathrm{CDCl}_{3}, 400 \mathrm{~Hz}\right): \delta$ 
(ppm) 10.439, 22.036, 66.917, 122.388, 128.090, 129.856, 132.452, 132.498, 135.690, 165.246;

Calculated for $\mathrm{C}_{10} \mathrm{H}_{11} \mathrm{BrO}_{2}$ [m+H. : 242.99, found 243.0; Physical state: Colourless liquid.

Propyl 4-iodo benzoate (Table 4, Entry 7): ${ }^{1} \mathrm{H} \mathrm{NMR}\left(\mathrm{CDCl}_{3}, 400 \mathrm{~Hz}\right): \delta(\mathrm{ppm}) 1.023(\mathrm{t}, 3 \mathrm{H}$, $J=7.6 \mathrm{~Hz}), 1.787$ (sextate, 2H, $J=7.6 \mathrm{~Hz}), 4.274(\mathrm{t}, 2 \mathrm{H}, J=6.8 \mathrm{~Hz}), 7.747$ (d, 2H, $J=8.4 \mathrm{~Hz}), 7.799$ $(\mathrm{d}, 2 \mathrm{H}, J=8.4 \mathrm{~Hz}) ;{ }^{1} \mathrm{H} \mathrm{NMR}\left(\mathrm{CDCl}_{3}, 400 \mathrm{~Hz}\right): \delta(\mathrm{ppm})$ 10.454, 22.052, 66.746, 100.494, 129.996, 130.972, 137.650, 166.091; Calculated for $\mathrm{C}_{10} \mathrm{H}_{11} \mathrm{IO}_{2}\left[\mathrm{~m}+\mathrm{H}^{+}\right.$: 290.98 , found 291.0; Physical state: Colourless liquid.

\subsubsection{Effect of re-usability of solid acids in the esterification of 3FBA with PrOH}

In order to study the reusability of solid acid catalysts, esterification of 3FBA with PrOH was carried with $0.05 \mathrm{~g}$ of $\mathrm{SZ}$ at $130{ }^{\circ} \mathrm{C}$ for $60 \mathrm{~min}$ under microwave irradiation. The solid acid catalyst (SZ) was recovered after the reaction by filtration, washed with ethyl acetate, dried in an oven at $120{ }^{\circ} \mathrm{C}$ for $1 \mathrm{~h}$ and calcined at $550{ }^{\circ} \mathrm{C}$ in a muffle furnace for $1 \mathrm{~h}$. Thus thermally regenerated solid acid catalyst was re-used in the next esterification reaction cycle. Such studies were carried out for 5 consecutive reaction cycles and the results are presented in Fig. 12. It can be seen from the figure that, not much change in the activity of re-activated SZ was observed in esterification reaction which indicates that the SZ solid acid can be effectively re-activated and re-used at least for 5 reaction cycles. 


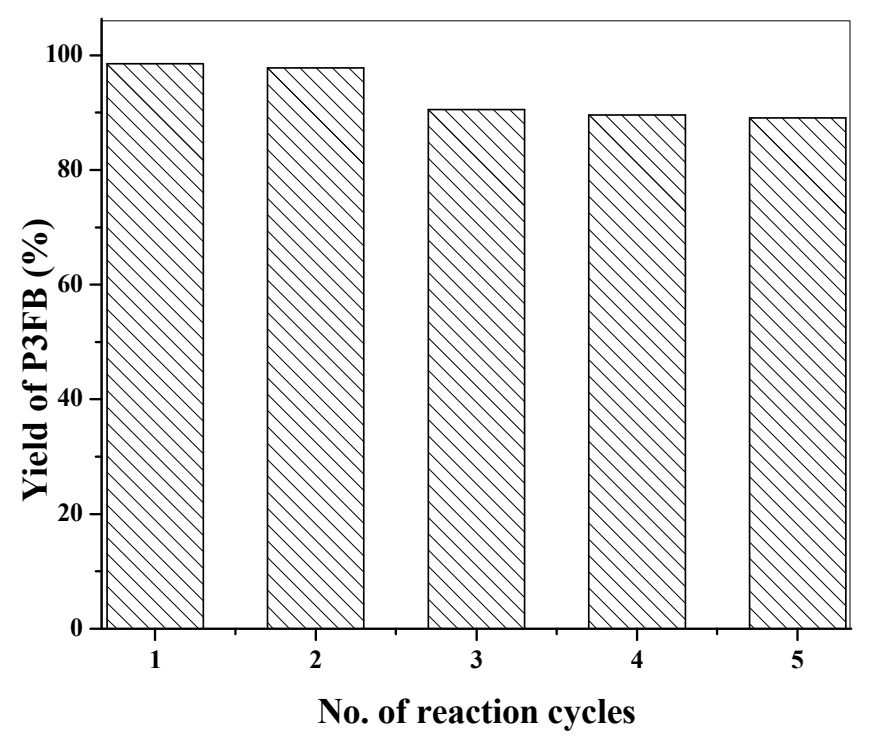

Figure 12. Effect reaction reusability on esterification of 3FBA with PrOH. [Reaction conditions: $0.05 \mathrm{~g}$ of $\mathrm{SZ}$ at $130{ }^{\circ} \mathrm{C}$ for $60 \mathrm{~min}$ under microwave irradiation, $3 \mathrm{FBA}=0.5 \mathrm{~g}$ and $\operatorname{PrOH}=2.7 \mathrm{~mL}]$

\section{Conclusion}

The catalytic materials like $\mathrm{ZrO}_{2}, 5 \mathrm{MZ}, 10 \mathrm{MZ}, 20 \mathrm{MZ}$ and $\mathrm{SO}_{4}{ }^{2-} / \mathrm{ZrO}_{2}$ are effective solid acid catalysts in the esterification reaction of halogenated aromatic carboxylic acids with propanol under $\mathrm{MW}$ heating conditions. $\mathrm{SO}_{4}{ }^{2-} / \mathrm{ZrO}_{2}$ could be used as a solid acid catalyst under microwave assisted synthesis of ester based reaction intermediates which are useful for the synthesis of drugs in shorter reaction times. Kinetic study showed that the esterification reaction follows pseudo-first order with reaction rate of $0.175 \mathrm{mmol} / \mathrm{min}$. The reactant pre-adsorption experiments suggested that the reaction follows the Langmuir-Hinshelwood mechanism. Further, $\mathrm{SO}_{4}{ }^{2-} / \mathrm{ZrO}_{2}$ was found to be reactivable and reusable up to five consecutive reaction cycles and can easily replace the conventional homogeneous Brönsted acid catalysts. 


\section{Acknowledgement}

Authors are grateful for the part financial support given by VGST, GoK (GRD-375/201415). Authors also thank the authorities of IISc, Bangalore for SEM, TEM, ${ }^{1} \mathrm{H}$ NMR, ${ }^{13} \mathrm{C}$ NMR and LCMS analysis. The authors are thankful to the department of chemistry St. Joseph's college, Bangalore for PXRD and FT-IR analysis and IITM, Chennai for TPD analysis of solid acids.

\section{References}

1. S. Z. Mohamed Shamshuddin and N. Nagaraju, J. Chem. Soc., 2010, 122 (2), 193-201.

2. J. Gimenez, J. Costa and S. Cevera, Ind. Eng. Chem., 1987, 26, 198-202.

3. A. Corma, H. Garcia, S. Iborra and J. Primo, J. Catal., 1989, 120, 78-87.

4. Z. H. Chen, T. Lizuka and K. Tanabe, K. Chem. Lett., 1984, 13 (7), 1085-1088.

5. P. T. Anastas and M. M. Kirchhoff, Acc. Chem. Res., 2002, 35, 686-694.

6. M. S. R. Murty, K. R. Ram, R. Venkateswara Rao, J. S. Yadav, J. Venkateswara Rao, R. Pamanji and L. R. Velatooru, Letters in Drug Design and Discovery, 2012, 9(3), 276-281.

7. S. Z. Mohamed Shamshuddin and N. Nagaraju, Catal. Commun., 2006, 7, 593-599.

8. S. Z. Mohamed Shamshuddin and N. Nagaraju, J. Mol. Catal. A: Chem., 2007, 273, 55-63.

9. R. J Kalbasi, A. R. Massah and Z. Barkhordari, Bull. Korean Chem. Soc., 2010, 31(8), 23612367.

10. L. N. P. Grijalva, D. Y. C. Gonzalez and L. L. Romero, Molecules, 2009, 14, 4065-4078.

11. M. Hino, S. Takasaki, S. Furuta, H. Matsuhashi and K. Arata, Appl. Catal. A: Gen., 2007, 321, 147-154. 
12. (a) G. D. Yadav and B. Kundu, Can. J. Chem. Eng., 2001, 79, 806-811. (b) Y. R. Girish, K. S. Sharath Kumar, U. Muddegowda, N. K. Lokanath, K. S. Rangappa and S. Shashikanth, RSC. Adv., 2014, 4, 55800-55806. (c) Y. R. Girish, K. S. Sharath Kumar, K. N. Thimmaiah, K. S. Rangappa and S. Shashikanth, RSC Adv., 2015, 5, 75533-75546.

13. X. T. Hu, Z. Zhou, D. F. Sun, Y. T. Wang and Z. B. Zhang, Catal. Lett., 2009, 133, 90-96.

14. S. Garg, K. Soni, G. M. Kumaran, R. Bal, K. Gora-Marek, J. K. Gupta, L. D. Sharma and G.M Dhar, Catal. Today, 2009, 141, 125-129.

15. B. A. Roberts and C. R. Strauss, Acc. Chem. Res., 2005, 38, 653-661.

16. B. A. Roberts and C. R. Strauss, "Microwave-Assisted Organic Synthesis”, P. Lidstrom, J. P. Tierney, Eds., Blackwell, Oxford 2005.

17. H. Desai, B. R. D’Souza, D. Foether, B. F. Johnson and H. A. Lindsay, Synthesis, 2007, 6, 902-910.

18. W. Tan, B. X. Zhao, L. Sha, P.F. Jiao and M. S. Wan, Synth. Commun, 2006, 36, 1353-1359.

19. N. F. K. Kaiser, U. Bremberg, M. Larhed, C. Moberg and A. Hallberg, Angew. Chem. Int. Ed., 2000, 39, 3595-3598.

20. G. Camelia, G. Sami, H. G. Edward, S. J. H. Ben and P.M. Michael, Chem. Soc. Rev, 1998, 27, 213-224.

21. D. R. Baghurst and D. M. P. Mingos, J. Chem. Soc. Chem. Commun., 1992, 674-677.

22. R. W. Johnson and M. Fritz, in Fatty Acids in Industry: Processes, Properties, Derivatives, Applications, ed. Marcel Dekker, New York, 1998. 
23. R. Giordanengo, S. Viel, M. Hidalgo, B. Allard-Breton, A. Thevand and L. Charles, Rapid Commun. Mass Spectrum, 2010, 24, 1941-1947.

24. N. S. Rajapaksa, M. A. Rienzo and E. N. Jacobsen, Org. Let., 2013, 15, 706-709.

25. T. O. Schrader, B. R. Johnson, L. Lopez, M. Kasem, T. Gharbaoui, D. Sengupta, D. Buzard, C. Basmadjian and R. M. Jones, Org. Let., 2012, 14, 6306-6309.

26. T. Mita, Y. Higuchi and Y. Sato, Chem-Eur. J., 2013, 19, 1123-1128.

27. S. P. Amanda, C. A. LeClair, E. Stefan, A. G. Turjanski, W. Maguire, S.A. Titus, R. Huang, D. S. Auld, J. Inglese, C.P. Austin, S. W. Michnick, M. Xia and C. J. Thomas, Bioorg. Med. Chem. Let., 2009, 19(13), 3686-3692.

28. Kamal. Ahmed, Med. Chem. Research, 2014, 23(4), 2080-2092.

29. C. Hadjipavlou, I. K. Kostakis, N. Pouli, P. Marakos, H. Pratsinis and D. Kletsas, Bioorg. Med. Chem. Lett., 2006, 16(18), 4822-4825.

30. L. Li, H. Ding, B. Wang, S. Yu, Y. Zou, X. Chai and Q. Wu, Bioorg. Med. Chem. Lett., 2014, 24(1), 192-194.

31. N. S. Hodnett, Synlett, 2003, 13, 2095-2096.

32. A. H. Zapien, J. M. H Enriquez, R. G. Alamilla, G. S. Robles, U. P. Garcia and L. A. G. Serrano, Advances in Materials Science and Engineering, 2014, http://dx.doi.org/10.1155/2014/432031.

33. N. Thimmaraju, S. R. Pratap, M. Senthilkumar and S.Z. Mohamed Shamshuddin, Korean Chem. Soc., 2012, 56(5), 563-570. 
34. N. Thimmaraju, S. Z. M. Shamshuddin, S. R. Pratap and Venkatesh, J. Mol. Catal A: Chem., 2014, 391, 55-65.

35. S. R. Kirumakki, N. Nagaraju, K. V. R. Chary and S. Narayanan, J. Catal., 2004, 221(2), $549-559$.

36. B. M. Reddy and V. R. Reddy, Synth. Commun., 1999, 29(16), 2789-2794.

37. Z. Yunfeng, Z. Huamin, H. Jingwei, Y. Baolian and J. Membrane Sci., 2006, 280, 148-155.

38. Sohn and J. R. Chun, Bull. Korean Chem. Soc., 2003, 24, 1785-1792.

39. K. V. R. Chary, K. R. Reddy, G. Kishan, J. W. Niemantsverdriet and G. Mestl, J. Catal., 2004, 226 (2), 283-291.

40. R. J. Madon and M. Boudart, Ind. Eng. Chem. Fundam., 1982, 21, 438-447.

41. G. Mitran, T. Yuzhakova, I. Popescu and I. C. Marcu, J. Mol. Catal. A: Chem., 2015, 396, $275-281$.

42. M. Sharma, A. P. Toor and R. K. Wanchoo, Chem. Biochem. Eng. Q., 2014, 28 (1), 79-82.

43. N. S. Ahmedzeki, M. Al-Hassani and H. Aljendeel, Al-Khwarizmi Eng. J., 2010, 25(2), 3342.

44. H. T. R. Teo, B. Saha, J. Catal., 2004, 228, 174-182.

45. K. Arata, Green Chemistry, 2009, 11, 1463-9270.

46. B. M. Reddy and M. K. Patil, Chemical reviews, 2009, 109, 2185-2208. 


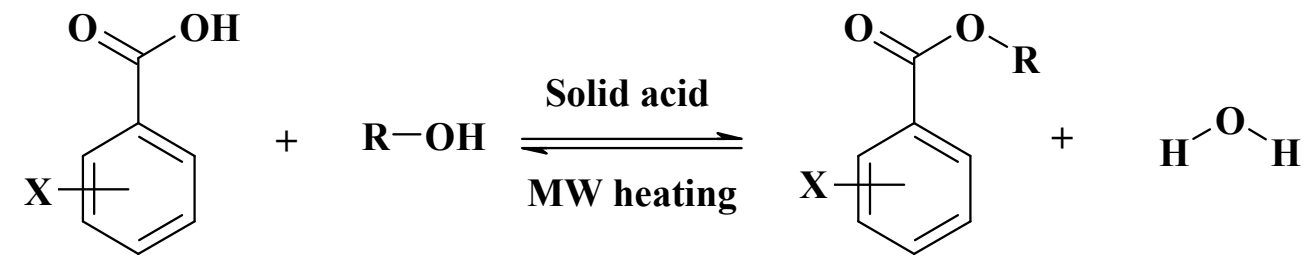

where, $\mathrm{X}=\mathrm{F}, \mathrm{Cl}, \mathrm{Br}$ and $\mathrm{I} ; \mathrm{R}=n$-propyl and iso-propyl group. 